NBER WORKING PAPER SERIES

\title{
ENLISTING EMPLOYEES IN IMPROVING PAYROLL-TAX COMPLIANCE: EVIDENCE FROM MEXICO
}

\author{
Todd Kumler \\ Eric Verhoogen \\ Judith A. Frías \\ Working Paper 19385 \\ http://www.nber.org/papers/w19385 \\ NATIONAL BUREAU OF ECONOMIC RESEARCH \\ 1050 Massachusetts Avenue \\ Cambridge, MA 02138 \\ August 2013
}

We would like to thank (without implicating) Emma Aguila for sharing information on tax rates and benefit formulas, Matthew Clifford for research assistance, and David Card, David S. Kaplan, Wojciech Kopczuk, Sebastian Galiani, François Gerard, Roger Gordon, Santiago Levy, Suresh Naidu, Ben Olken, Kiki Pop-Eleches, Bernard Salanié, Monica Singhal and many seminar participants for helpful conversations. Verhoogen gratefully acknowledges the support of the National Science Foundation (SES-0721068). The views expressed in this paper are those of the authors, and do not necessarily reflect the views of the Instituto Mexicano del Seguro Social or the National Bureau of Economic Research. This paper was previously circulated under the title, "Enlisting Workers in Monitoring Firms: Payroll Tax Compliance in Mexico" (Kumler et al, 2012).

NBER working papers are circulated for discussion and comment purposes. They have not been peerreviewed or been subject to the review by the NBER Board of Directors that accompanies official NBER publications.

(C) 2013 by Todd Kumler, Eric Verhoogen, and Judith A. Frías. All rights reserved. Short sections of text, not to exceed two paragraphs, may be quoted without explicit permission provided that full credit, including $(\mathcal{C}$ notice, is given to the source. 
Enlisting Employees in Improving Payroll-Tax Compliance: Evidence from Mexico

Todd Kumler, Eric Verhoogen, and Judith A. Frías

NBER Working Paper No. 19385

August 2013, Revised April 2015

JEL No. H26,H55,O17

\begin{abstract}
$\underline{\text { ABSTRACT }}$
A growing body of research suggests that difficulties in collecting taxes are an important constraint on economic performance in developing countries. Evidence from rich countries points to third- party reporting - in particular, employer reports of employees' wages — as a potential remedy. To what extent does the accuracy of third-party reporting carry over to developing countries, with their weaker enforcement regimes? In this paper, we compare two sources of wage information from Mexico firms' reports of individuals' wages to the Mexican social security agency and individuals' responses to a household labor-force survey — to investigate the extent of wage under-reporting by formal firms and how it responded to an important change in the social security system. We document that under-reporting is extensive, and that compliance is better in larger firms. Using a difference-in-differences strategy based on the 1997 Mexican pension reform, which effectively tied pension benefits more closely to reported wages for younger workers than for older workers, we show that the reform led to a relative decline in under-reporting for younger age groups. This result reinforces the view that the discrepancies between the two data sources can be interpreted as evidence of evasion, and suggests that giving employees incentives and information to improve the accuracy of employer reports can be an effective way to improve payroll-tax compliance.
\end{abstract}

Todd Kumler

Department of Economics

Columbia University

420 West 118th Street, MC3308

New York, NY 10027

tjk2110@columbia.edu

Eric Verhoogen

Department of Economics

School of International \& Public Affairs

Columbia University

420 W. 118th Street

New York, NY 10027

and NBER

eric.verhoogen@columbia.edu
Judith A. Frías

Instituto Mexicano del Seguro Social

Paseo de la Reforma No. 476

Col. Juárez, 06600 México D.F., México

judith.frias@imss.gob.mx 


\section{Introduction}

A growing body of research suggests that lack of fiscal capacity — in particular, difficulty in raising taxes to fund public goods - is an important constraint on economic performance in developing countries (Burgess and Stern, 1993; Besley and Persson, 2013). Developing countries generally have low ratios of tax revenues to GDP and large informal sectors. Mexico, the focus of our study, is no exception: it has the lowest tax revenue share of GDP in the OECD, between 15 and 20 percent during the period we study, and the informal sector has been estimated to make up 40 percent or more of total output (OECD, 2011b; IMF, 2010; Schneider and Enste, 2000). Given weak enforcement institutions and widespread evasion, the task of improving fiscal capacity in developing countries is a difficult one, and there is acute interest among researchers and policy-makers in potential remedies.

Evidence from rich countries points to third-party reporting - specifically, employer reports of employees' wages - as a potentially promising solution. Careful studies of the "tax gap" by the U.S. Internal Revenue Service indicate that in 2001 about 57 percent of non-farm proprietor income but only one percent of wages and salaries went unreported (Internal Revenue Service, 2006; Slemrod, 2007). Saez (2010) finds significant bunching around the first kink point of the Earned Income Tax Credit, suggesting misreporting, only among the self-employed. In a randomized audit study in Denmark, Kleven, Knudsen, Kreiner, Pedersen, and Saez (2011) find little evasion when incomes are reported by employers or other third parties. The view that third-party reporting is effective in ensuring compliance is widespread among practitioners and government agencies (see e.g. Plumley (2004) and OECD (2006)).

To what extent does the accuracy of third-party reporting carry over to developing countries, with their generally weaker enforcement regimes? In this paper, we draw on rich micro-data from Mexico to estimate the extent of wage under-reporting by formal firms and how it responded to an important change in the Mexican social security system. To measure under-reporting, we compare two sources of detailed wage information - firms' reports of individuals' wages to the Mexican social security agency and individuals' responses to a household labor-force survey (the Encuesta Nacional de Empleo Urbano (ENEU)). We construct three measures of evasion for different demographic groups, based on the median and mean wage differences between the two datasets and the excess mass in the social security data to the left of a given cut-off in the household data.

In cross-sectional results, we find evidence of substantial under-reporting of wages by formal firms. We also find that evasion is declining in firm size. We believe that this paper is the first to document systematic differences in wage under-reporting by firm size among formal firms. This finding is consistent with a simple partial-equilibrium model of endogenous compliance by heterogeneous firms which we summarize briefly in Section 3 and present in full in Appendix B 
(online). The cost of evasion is assumed to be increasing both in the unreported part of the wage per worker and in firm output, for reasons that may include the greater difficulty of maintaining collusion in larger firms, as argued in a recent paper by Kleven, Kreiner, and Saez (2009), or simply the greater visibility of larger firms to auditors. The finding that compliance is increasing in firm size is consistent with the suggestion of Hsieh and Klenow (2014) and Hsieh and Olken (2014) that the burden of taxation in developing countries falls more heavily on larger firms and that this is part of the explanation for the disproportionately large number of small firms in Mexico and other developing countries.

We also show that evasion responded to an important change in the Mexican social security system in the way that our simple economic model would predict. We focus on a pension reform that introduced a system of personal retirement accounts, passed by the Mexican Congress on December 21, 1995 and implemented on July 1, 1997. As discussed in more detail below, prior to the reform the social security benefits of most workers were insensitive to the wages reported by firms on their behalf, as long as they reported at least the minimum allowable wage. The reform tied individual pensions more closely to firms' wage reports and made it easier for employees to observe those reports. Workers already in the traditional system prior to July 1, 1997 retained the right to choose, at the time of retirement, the pension that they would have received under the pre-reform regime. Because older workers had little time to accumulate sufficient balances in their personal accounts, their expected pension was higher under the old regime. Younger workers had a greater expectation of being better off under the new regime and hence had stronger incentives to ensure accurate reporting. We use this differential impact by age as the basis for a difference-indifferences estimation strategy. Consistent with our theoretical model, evasion declines relatively more for younger age groups. The fact that the discrepancies between the two data sources move in the way predicted by theory reinforces the view that they are a meaningful measure of evasion and suggests that giving employees incentives and information to improve the accuracy of employer reports can be an effective way to improve payroll-tax compliance.

While we have arguably richer data than have been available in the previous literature on payroll-tax compliance in developing countries, a key data limitation is that the household laborforce survey does not contain firm identifiers and we are not able to construct measures of evasion at the firm level. Instead, we construct measures of evasion at the level of cells defined by different combinations of metropolitan areas, sectors, firm-size categories and age groups, depending on the specification. A second limitation is that it is difficult to separate the effects of the change of incentives and the change of information with the pension reform (discussed in more detail in Section 2). It seems likely that the change in incentives was more important than the change in information: if incentives had not changed, and benefits had remained largely insensitive to wage reports, it is not clear why information alone would have led to changes in compliance. But the "experiment" we consider combined both elements, and the effects we estimate should be 
interpreted as the combined effects of both. ${ }^{1}$

This paper is related to a number of different literatures. Research in development economics on the non-compliance of firms with tax regulations has tended to focus on the the failure of firms to register with tax authorities, which we might term the extensive margin of compliance (Gordon and Li, 2009; McKenzie and Sakho, 2010; de Mel, McKenzie, and Woodruff, 2012). In this paper, by contrast, we focus on an intensive margin of compliance: the extent of compliance by formally registered firms, reporting wages for formally registered workers.

There is a small literature on salary misreporting, including Nyland, Smyth, and Zhu (2006), Tonin (2011), and Bérgolo and Cruces (2012), and Mao, Zhang, and Zhao (2013). This paper appears to be the first to analyze how tying benefits more closely to reported wages can contribute to improved compliance. ${ }^{2}$ This paper is also distinctive in using the comparison of firms' administrative reports to workers' responses to a household survey to measure evasion. ${ }^{3}$ It is also the first in this literature to explicitly consider the role of firm heterogeneity in evasion. ${ }^{4}$

This paper is related to recent work on incentivizing decentralized agents to improve tax enforcement. Kopczuk and Slemrod (2006), Keen and Lockwood (2010), and Pomeranz (2013) argue that value-added taxes (VATs) have attractive enforcement properties in part because they give each party in a supply-chain transaction greater incentive to ensure that the other reports accurately. A recent paper by Naritomi (2013) analyzes a Brazilian program to give consumers incentives to ask for receipts from retail establishments and finds positive effects on compliance. Khan, Khwaja, and Olken (2014) find that randomized incentives to tax inspectors in Pakistan increase tax revenues.

More broadly, this paper is in the spirit of a growing empirical literature in development economics examining how corruption and other forms of illegal behavior respond to economic incentives, recently surveyed by Olken and Pande (2012). It is part of a small but growing literature using administrative records from developing countries to document various aspects of taxpayer behavior (Pomeranz, 2013; Kleven and Waseem, 2013; Best, Brockmeyer, Kleven, Spinnewijn, and Waseem, forthcoming). It is also related to an active recent literature on the role of firms in tax systems (Kopczuk and Slemrod, 2006; Gordon and Li, 2009; Dharmapala, Slemrod,

\footnotetext{
${ }^{1}$ Our argument should not be interpreted as advocating a system of personal accounts per se; one could imagine a change in pension benefits under the traditional pay-as-you-go system that would have had similar effects.

${ }^{2}$ Bailey and Turner (2001) suggest verbally that tying pension benefits to contributions would have the effect of reducing evasion.

${ }^{3}$ Papers using the general strategy of comparing information from more than one data source to infer illicit behavior (in other contexts) include Pissarides and Weber (1989), Fisman and Wei (2004), Olken (2006), Gorodnichenko, Martinez-Vazquez, and Peter (2009), Marion and Muehlegger (2008), Hurst, Li, and Pugsley (2011), Braguinsky, Mityakov, and Liscovich (2010), and Niehaus and Sukhtankar (forthcoming).

${ }^{4} \mathrm{~A}$ recent paper by Best (2014), which appeared after the current paper was circulated, considers heterogeneity across firms based on firms' and individuals' reports to the tax authority in Pakistan. But it does not have a source of wage information not subject to misreporting incentives, and to the extent that firms and workers collude the difference between the firms' and workers' responses is likely to be an inaccurate measure of the extent of misreporting.
} 
and Wilson, 2011) and to a voluminous literature on tax evasion and avoidance, reviewed by Andreoni, Erard, and Feinstein (1998), Slemrod and Yitzhaki (2002), and Saez, Slemrod, and Giertz (2012).

\section{Institutions: The Mexican Social Security System}

Because our empirical strategy relies crucially on incentives in the Mexican social insurance system, this section describes the system and the pension reform in some detail. Because of data constraints, discussed in more detail below, we focus on the years 1988-2003. In describing the characteristics of the social security system and in the empirical work below, we will focus primarily on male workers. ${ }^{5}$

The Instituto Mexicano del Seguro Social (IMSS), the Mexican social security agency, is the primary source of social insurance for private-sector workers in Mexico. It administers pension benefits, disability insurance, work injury compensation, childcare centers, and a large number of clinics and hospitals, which are the primary source of health care for the formal, private-sector Mexican workforce. ${ }^{6}$ Beginning with its creation in 1944, IMSS operated as a pay-as-you-go (PAYGO) scheme financed by payroll taxes. By the late 1980s, however, rising health care costs and an increase in the number of pensioners relative to the working-age population led to projected shortfalls in the IMSS financial accounts. On Dec. 21, 1995, because of concerns about the financial viability of the system, the congress enacted a comprehensive pension reform, to take effect on July 1, 1997. ${ }^{7}$ This reform replaced the entire PAYGO pension system with a system of personal retirement accounts (PRA). More extensive discussions of the pension reform are provided in Grandolini and Cerda (1998), Sales-Sarrapy, Solis-Soberon, and Villagomez-Amezcua (1996), and Aguila (2011).

\subsection{Contribution Rates}

IMSS requires contributions from both employers and employees based on reported wages; these are supplemented by government contributions. Figure 1 presents the contribution schedule for

\footnotetext{
${ }^{5}$ The incentives and empirical patterns for women are complicated by the facts that women's labor force participation changed relatively rapidly over the study period and that many women receive IMSS benefits through their spouses, which provides an incentive to remain in the informal sector. In addition, because of relatively low labor force participation by older women, sample sizes in the ENEU household survey (described below) are often inadequate, especially when analyzing the data separately by metropolitan area (or metropolitan area, firm size and sector), as explained below. We present the main tables and figures for women in Appendix D (online). To preview the results, the cross-sectional patterns are robust for women, but the difference-in-differences results are not, possibly for the reasons just discussed.

${ }^{6}$ Public-sector workers and workers for PEMEX, the state-owned oil company, are covered by separate systems. In 2003, the government created an alternative system called Seguro Popular, which provides basic health coverage for all individuals and is not tied to formal employment. In this paper, we focus on the IMSS system and sectors with minimal government employment.

${ }^{7}$ This change followed an unsuccessful partial reform in 1992, described in Appendix A.1.
} 
employers as a function of the reported real daily wages of each employee, for selected years. The schedule reflects a complicated set of formulas determining contributions to the various components of the IMSS system, principally health care, pensions, and child care. ${ }^{8}$ The figure illustrates that the most significant changes in the schedule are for the highest-wage workers, earning above 500 pesos per day, due to changes in the maximum taxable income over the period, from 10 times to 25 times the minimum wage in Mexico City. ${ }^{9}$ The topcodes apply to no more than 5 percent of wage-earners in any year and will play little role in our analysis. The total employer contribution varied between 18 percent and 22 percent of the wage over the range in which almost all workers fall. There was an increase in the employer contribution from 1990 to 1993, and then the reform in 1997 introduced a kink in the schedule, which raised contributions disproportionately on the lowest-wage workers. Figures 2 displays worker contributions, which vary between 2 percent and 5 percent over the relevant range and declined with the 1997 reform. Overall, while there were changes in the contribution schedules, these were relatively modest over the relevant wage range. ${ }^{10}$ Looking ahead to the empirical strategy, we also note that the changes in contributions were the same for all age groups and their effects will be differenced out in our difference-in-differences procedure.

\subsection{Non-pension Benefits}

Any worker on whose behalf contributions are made to the system is entitled to free health care at IMSS hospitals and clinics, for himself or herself, as well as for members of his or her immediate family, independent of the reported wage. In addition, working mothers and widowed or divorced working fathers are entitled to free child care during workdays for children under four years old. ${ }^{11}$ It is difficult to estimate workers' valuations of these non-pension benefits. Conveniently for our empirical strategy, however, the health care and child care benefits did not change with the 1997 pension reform. Under the assumption that employees' valuations of the constant set of benefits did not change differentially by age group over the study period, the valuations will be differenced out in our difference-in-differences procedure. ${ }^{12}$

\footnotetext{
${ }^{8}$ Full details are presented in Appendix Tables A1 and A2 (online).

${ }^{9}$ There are three minimum wage zones in Mexico, corresponding to higher-, medium- and lower-wage municipalities, respectively. The minimum wage in Mexico City is typically used for indexing purposes, and where we refer to the minimum wage (without specifying zone) we are referring to the minimum wage in Mexico City.

${ }^{10}$ Although the kink introduced in 1997 appears promising for econometric analysis, we do not find evidence of significant bunching at the kink point. While the changes in topcodes also appear promising, we lack sample size, particularly in the household data, to exploit them, at least using the strategy of the current paper.

${ }^{11}$ IMSS also provides an individual savings account for housing expenditures, which in some cases can be used to contribute to an individual pension. See Appendix A.2 (online) for details.

${ }^{12}$ There has been a secular decline in the number of IMSS hospital and clinic beds per covered individual, but there was no trend break in 1997 (IMSS, 2011, ch. 11). Below we will find no pre-trend in under-reporting prior to 1997.
} 


\subsection{Pension Benefits}

\subsubsection{Pre-reform (pay-as-you-go) system}

Under the pre-reform regime, workers became vested in the system after 10 years of contributions, and were then entitled to receive at least the minimum pension. Pensions were calculated on the basis of the final average wage, defined as the average nominal wage in the five years preceding retirement. Panel A of Figure 3 illustrates the expected daily pension as a function of the final average wage for workers with 10,20 and 30 years of contributions in selected years. The schedules combine a minimum pension guarantee with a benefit proportional to an individual's wage. At first glance, the pension values illustrated in Panel A appear to be sensitive to the reported final average wage, but it is important to note that in the years leading up to the reform inflation had severely eroded the real value of wages and pensions, such that a large majority of workers had final average wages in the region in which the minimum was binding. Inflation exceeded 50 percent in every year in the volatile 1982-1988 period, and exceeded 100 percent in 1987 and 1988; it was above 25 percent in a number of subsequent years (1990-1991 and 1995-1996). (See Appendix Table A4 (online).) In response to public pressure, the Mexican Congress in 1989 increased the minimum pension to 70 percent of the minimum wage and indexed it to the minimum wage going forward, without raising the value of pensions greater than the minimum. ${ }^{13}$ The congress subsequently raised the value of the minimum pension relative to the minimum wage, until it reached 100 percent of the minimum wage in Mexico City in 1995.

As a consequence of the erosion of the real value of pensions above the minimum and the legislative interventions to raise the minimum, the fraction of workers who expected to receive the minimum pension remained high throughout the pre-reform period. Panel B of Figure 3 plots the real value of the pension for male workers with 10, 20 or 30 years of contributions against the final average wage percentile of 60-65 year old men in the IMSS data, for selected years. ${ }^{14}$ In 1990 , approximately 80 percent of male retirees with 10 years of contributions received the minimum pension. The corresponding numbers for male workers with 20 or 30 years of contributions were 70 percent and 60 percent respectively. In 1997, just prior to the implementation of the pension reform, nearly all workers with 10 years of contributions, roughly 50 percent of those with 20 years, and 40 percent of those with 30 years could expect to receive the minimum pension. ${ }^{15}$

\footnotetext{
${ }^{13}$ In 1991, benefits were indexed to the minimum wage, which slowed the erosion of the values of pensions above the minimum. That is, if a worker's final average wage was twice the minimum wage in 1991, the pension payment in 1992 was calculated on the basis of twice the minimum wage. The real minimum wage declined steadily over the period (see Appendix Table A4 (online)) so the slowing of the erosion of pensions as a result of this change was modest.

${ }^{14}$ To calculate the final average wage percentile, we calculate the nominal wage at each percentile of the IMSS wage distribution for 60-65 year old men in each of preceding five years, then take the average for each percentile.

${ }^{15}$ In addition, there was a penalty for retirement before age 65 of 5 percent per year (i.e. a worker who retired at age 60 would have his or her pension reduced by 25 percent), but this penalty was not allowed to reduce the pension below the minimum. This reduced the disincentive to retire early to workers with pensions near the minimum (Aguila, 2011).
} 
Unfortunately, the data to which we have access do not contain total years of contributions by each individual worker, and hence we are not able to calculate the precise number of workers receiving the minimum pension. But analysts with access to this information report that approximately 80 percent of retirees were receiving the minimum pension prior to the reform (Grandolini and Cerda, 1998). ${ }^{16}$

Strictly speaking, pension values were insensitive to final wages only for infra-marginal workers whose true final wage corresponded to the minimum pension. If wages were under-reported to IMSS, as we argue below, then the graphs in Panel B of Figure 3 likely overstate the fraction of workers whose pensions were insensitive to under-reporting. To address this, in Panel $\mathrm{C}$ of Figure 3 we plot similar graphs using final average wage percentiles calculated from the ENEU household data (described in Section 4 below), which should not be subject to under-reporting. We see that somewhat smaller fractions of workers with 10, 20 and 30 years of contributions would have received the minimum pension. But the key point is that the graph for 1997 resembles quite closely the corresponding graph in Panel B: essentially all workers with 10 years of contributions would have received the minimum pension, as well as more than 40 percent of workers with 20 years and more than 20 percent of workers with 30 years.

\subsubsection{Post-reform (personal retirement accounts) system}

Under the personal retirement account (PRA) system, employees, employers and the government are required to make contributions to workers' personal retirement accounts in each period. ${ }^{17}$ Each worker is required to choose an investment institution, known as an Administrador de Fondos de Ahorro para el Retiro (AFORE) [Retirement Savings Fund Administrator], to manage his or her account. ${ }^{18}$ The reform also specified a minimum pension equal to the minimum wage on July 1, 1997, with further increases in the minimum pension indexed to the Consumer Price Index. Eligibility for the minimum pension was raised from 10 years of contributions to 25 years of contributions.

The establishment of the new pension regime created two categories of workers: "transition" workers who first registered with IMSS before July 1, 1997, and new workers who first registered after July 1, 1997. At retirement, transition workers are given a choice between receiving pension

\footnotetext{
${ }^{16}$ In addition, because pensions were calculated only on the basis of the last five years of employment, any worker who was certain that he or she would work for more than five years in covered employment could also be certain that the current reported wage would not affect the pension benefit. In unreported results, we have investigated whether we see an increase in reported wages five years before retirement, as one might expect if workers were being sophisticated in adjusting strategically to the five-year rule, but we do not find a significant change.

${ }^{17}$ Over the 1997-2003 period, employers were required to contribute 5.15 percent of each employee's wage, and employees 1.125 percent; the government contributed 0.225 percent, as well as a "social quota" equal to 5.5 percent of the current minimum wage in Mexico City. See Appendix Tables A1 and A2 for details. Employees also have the option to contribute to a voluntary retirement savings account. See Lara-Ibarra (2011) for an analysis of the effects of a change in the tax rate on these contributions.

${ }^{18}$ The AFORE management fees are in many cases substantial, and it is not clear that workers choose AFOREs optimally. Duarte and Hastings (2010) investigate the role of behavioral issues in employees' choices of AFOREs.
} 
benefits under the PAYGO scheme or the PRA scheme. The PAYGO pension is calculated as if workers' post-reform contributions were under the old regime. If a transition worker opts for the PAYGO pension, IMSS appropriates the balance of his or her personal retirement account. The only option for new workers is the PRA. ${ }^{19}$

To illustrate the impact of the reform on pension wealth, we conduct a simulation of pension wealth under the two regimes, based on a similar simulation by Aguila (2011). In carrying out the simulation, we choose a relatively optimistic annual return on the personal accounts: 8.59 percent, the average return from 1998-2002, as in the more optimistic of the two scenarios considered by Aguila (2011). We also assume that participants expected the real value of the minimum wage to decline, as it had done for more than a decade (see Appendix Table A4). Assumptions of lower interest rates and less rapid declines in the real minimum wage would be less favorable to the PRAs. Details of the simulation are in Appendix A.3 (online).

One way to see the differences in incentives by age in the system is to compare pension wealth for workers of different ages in 1997. Table 1 displays the real present value of pension wealth by wage level for male workers of different ages in 1997, all of whom began working at age 25 and expect to continue working until age 60, assuming real wages are constant over their lifetimes. Numbers in italics (and in blue where color is available) indicate that the PRA pension is more valuable than the PAYGO pension. The message of the simulation is clear: the PRA pension is expected to be more valuable only for younger workers who expect to contribute to the personal account for 25 or more years, and among these workers the PRA pension is relatively more attractive for higher-wage workers. ${ }^{20}$

We do not attempt to infer from the simulation exact crossing points at which the PRA becomes preferable to the PAYGO pension; any such calculation would be sensitive to assumptions about the path of interest and inflation rates, and it is not clear that workers are sophisticated in calculating the precise values of pensions under the different systems. The basic message of the simulation, which we believe was understood by participants at the time of the reform, is that for most workers, conditional on qualifying for the minimum pension under the old regime,

\footnotetext{
${ }^{19}$ Under the personal-account system, individuals have three options upon retirement. One is to receive programmed withdrawals from the individual's AFORE, where the withdrawal amount is calculated based on the account balance as well as the age and life expectancy of the individual and dependents. (A worker who receives the minimum pension must choose this option.) A second option is to purchase an annuity from a private insurance company that guarantees a fixed monthly pension. A third option, available to workers with a personal-account balance exceeding 130 percent of the cost of an annuity providing a monthly payment equal to the minimum pension, is to take a lump-sum payment upon retirement.

${ }^{20}$ Another way to see the effect of the reform is to consider the values of the pensions for different numbers of years of expected contributions, for a worker who entered the system on June 30, 1997, as presented in Appendix Table A5. Note that workers with fewer than 10 years of contributions are better off under the new regime, since they receive no pension under the old regime but a small pension under the new regime. But conditional on a worker having at least 10 years of contributions, we again see that the attractiveness of the PRA pension is increasing in the number of years of contributions and the wage. The median wage for male workers is just above 100 pesos/day, and for a worker at this level the PRA only becomes more attractive if he expects to contribute for more than 25 years.
} 
the personal accounts could be expected to be relatively more attractive only for workers with a significant number of years of contributions after 1997.

Another aspect of the pension reform, which may have been important in practice, is that the law requires AFOREs to send an account statement to each holder of a personal retirement account every four months. A redacted example of such an account statement appears as Figure 4. The account statement reports previous balances (saldo anterior), new contributions (aportaciones), withdrawals (retiros), interest earned (rendimientos), AFORE commissions charged (comisiones), and final balances (saldo final) for the pension account as well as for the voluntary savings account (see footnote 17) and the housing savings account (see footnote 11). The bottom section reports 3-year returns and commissions for each AFORE, as well as the average 5-year net return (at left). It appears that these account statements made it significantly easier for workers to discover how much employers were contributing on their behalf. This mechanism would not be expected to reduce evasion if employers and employees were colluding in under-reporting wages, but it may have reduced evasion in cases in which workers were unaware that their employers were under-reporting their wages.

Neither before nor after the reform was there a reward to employees for revealing evasion by their employers, beyond ensuring accurate reporting of their own wages. The social security law provides for fines if establishments are caught evading taxes. The fines ranged from 70-100 percent of the amount of evasion over the 1995-2001 period and have ranged from 40-100 percent, with most exactly at 40 percent, since $2001 .^{21}$ Although we argue that evasion has been widespread, at least one aspect of IMSS reporting requirements does appear to have been strictly enforced. By law, firms in Mexico are required to pay the relevant minimum wage and a holiday bonus called an aguinaldo, worth two weeks of salary - approximately 4.5 percent of annual earnings. In order to avoid fines, establishments are required to report wages of at least the corresponding minimum wage plus 4.5 percent throughout the year. ${ }^{22}$

\subsection{Other Dimensions of Tax System in Mexico}

One reason that firms in developed countries engage in relatively little under-reporting of wages may be that it does little to reduce their overall tax burden. If corporate or personal income taxes are as high as payroll taxes and difficult to evade, then lower payroll taxes due to under-reporting will be offset by higher taxes on corporate or personal income. In Mexico, the corporate income tax is generally higher than the payroll tax on paper: it went from 39 to 34 percent over the 1988-2003 period. $^{23}$ But corporate tax evasion and avoidance are rife in Mexico. For instance,

\footnotetext{
${ }^{21}$ In addition, the law requires employers with 300 or more employees are required to submit an audit by a certified public accountant to IMSS (since 1993) as well as to the Mexican tax authority (since 1991).

${ }^{22}$ Prior to 1991 , there are a scattered few reports of wages below this level; beginning in 1991, IMSS stepped up enforcement of this rule and such wages have no longer been observed.

${ }^{23}$ Source: OECD Tax Database, www.oecd.org/ctp/taxdatabase.
} 
the OECD in 1992 found that, in part due to various loopholes, 70 percent of corporate tax declarations reported no taxable income (OECD, 1992). By all accounts, tax evasion remains high (OECD, 2011a). In addition, the social security agency and the Mexican tax authority first signed an agreement to share data in June 2002; thus for almost all of the period under study, there was no chance that information reported to the social security agency would affect the corporate tax burden. It appears, in other words, that evaded payroll taxes were not offset by increases in other taxes.

Also, it does not appear that individual income taxes provided a strong disincentive to most workers to have their wages reported accurately. Mexico provides extensive tax credits for lowwage workers, originally instituted to offset the regressive effects of VATs, with the consequence that many workers legally pay no income tax, or even receive funds from the tax authority (i.e. face a negative income tax.) In 1997, for instance, individuals making less than 3.2 times the minimum wage in Mexico City faced a zero or negative tax rate (OECD, 1999, p. 80).

\section{Conceptual Framework}

To organize our empirical analysis, we have developed a simple partial-equilibrium model of the compliance decisions of heterogeneous firms, in which employees and firms collude in underreporting (as in Yaniv (1992)) and firms are monopolistically competitive and differ in productivity (as in Melitz (2003)). The model shares with a number of existing models that less-able entrepreneurs, whose firms are smaller, comply less than more-able entrepreneurs (Rauch, 1991; Dabla-Norris, Gradstein, and Inchauste, 2008; De Paula and Scheinkman, 2011; Galiani and Weinschelbaum, forthcoming) but differs in that we consider partial compliance: wage under-reporting by formally registered firms, as opposed to a binary decision about whether to register. ${ }^{24}$ To save space in the main text, we have put the full model in Appendix B; here we briefly summarize the main ideas.

Let $w_{r}$ be the pre-tax wage reported by a firm to the government, $w_{u}$ the unreported wage (paid "under the table"), and $\tau$ the tax rate (the sum of firm and worker contributions). Then the the net take-home wage received by workers is $w_{n e t}=w_{u}+(1-\tau) w_{r}$. Rearranging,

$$
w_{u}=w_{n e t}-(1-\tau) w_{r}
$$

\footnotetext{
${ }^{24}$ Three other recent papers discuss heterogeneity of firms' tax-compliance decisions. Kleven, Kreiner, and Saez (2009) consider a particular mechanism that generates greater compliance among larger firms — the increasing difficulty of maintaining collusion as the number of employees increases - but do not focus on differential responses to tax or benefit changes. Besley and Persson (2013, pp. 103-105) note that if compliance costs depend on firm size, then firm heterogeneity will matter for compliance, without taking a position on the source of the firm heterogeneity or on the implication for responses to tax changes. Dharmapala, Slemrod, and Wilson (2011) consider the optimal taxation of firms in a setting with firm heterogeneity and the implications for firm size distributions, but do not focus on wage under-reporting.
} 
In the empirics, $w_{r}$ will correspond to the wage reported by the firm in the administrative records of the social security agency and $w_{n e t}$ to the take-home pay reported by workers in the ENEU household survey. As mentioned above and discussed in more detail below, we do not observe $w_{\text {net }}$ at the firm level, but we do observe it - and will be able to construct measures of the unreported wage - at a more aggregated level.

We assume that the cost of evasion is given by $x c\left(w_{u}\right)$, where $c^{\prime}\left(w_{u}\right)>0, c^{\prime \prime}\left(w_{u}\right)>0$ and $x$ is the output of the firm. One possible justification for this assumption is simply that auditors are more likely to audit larger firms because their operations are more visible, as suggested by Besley and Persson (2013, p. 66) - a conjecture that appears anecdotally to be relevant in Mexico. Another is the argument of Kleven, Kreiner, and Saez (2009) that collusion in under-reporting is more difficult to sustain in larger firms. Whatever the underlying mechanism, the assumptions on the cost-of-evasion function give us our first key theoretical implication: in equilibrium, more productive firms, which are larger, choose to evade less.

In our static setting, we model the per-period value of the future pension benefit as $b w_{r}$, where we call $b$ the "benefit rate." We assume that $b<\tau$, which corresponds to the Mexican institutional setting, where the tax payment includes contributions for health care (which are not sensitive to reported wages) as well as pension benefits (which may be). This assumption means that there is a rent to not reporting wages at the margin (some of which may be shared with employees); firms will weigh their share of this rent against the costs of evasion. The total effective wage, inclusive of pension benefits, which we denote by $w_{e}$, is then (using (1)):

$$
w_{e}=w_{n e t}+b w_{r}=w_{u}+(1-(\tau-b)) w_{r}
$$

We assume that the labor market is competitive and that workers' labor supply responds to the effective wage, $w_{e} \cdot{ }^{25}$ It can be shown that an increase in the benefit rate, $b$, will lead firms to rely more heavily on the reported wage, $w_{r}$, in the compensation package to achieve a given marketclearing effective wage. This is our second key theoretical implication: an increase in the pension benefit rate will lead to a decrease in the unreported wage, $w_{u}$, within each firm. The model considers homogeneous workers, but could be easily extended to consider more than one type of worker, who differ in the benefit rate they face. We would then expect the unreported wage, $w_{u}$, to decline more for workers who face a greater increase in the benefit rate, $b{ }^{26}$

An important issue in this context is the incidence of the change in the pension benefit rate on wages. Theoretically, it is possible to show that, for a finite labor-supply elasticity, the effective wage, $w_{e}$, is increasing in the benefit rate, $b$. If $b$ rises, the government ends up paying a larger

\footnotetext{
${ }^{25}$ We assume that workers observe both $w_{n e t}$ and $w_{r}$, and hence $w_{u}$ and $w_{e}$. In this sense, workers collude in under-reporting in that they are aware of it and do not report it.

${ }^{26}$ An additional implication of the model is that a decrease in the tax rate, $\tau$, has an analogous effect to an increase in the benefit rate on compliance; we return to this below.
} 
share of the effective wage and some of this increased contribution redounds to workers. But in general it is not possible to sign the effects of the reform on the observable wage measures, the firm-specific reported wage, $w_{r}$, or the firm-specific take-home wage, $w_{n e t}$, for reasons discussed in the appendix. It is worth emphasizing, however, that in the model the response of $w_{u}$ to the policy change does not depend on the incidence of the policy change on $w_{e}, w_{r}$ or $w_{n e t}$. In this sense, the model suggests that it is reasonable to examine the effect of the policy change on evasion separately from the question of incidence, which is how we proceed in the empirical analysis.

\section{Data}

The establishments' wage reports are drawn from IMSS administrative records. All private Mexican employers are in principle legally obligated to report wages for their employees, and pay social-security taxes on the basis of the reports. The IMSS dataset contains the full set of wage reports for employees in registered, private-sector establishments over the period 1985-2005. ${ }^{27}$ The dataset contains a limited set of variables: age, sex, daily wage (including benefits), state and year of the individual's first registration with IMSS, an employer-specific identifier, and industry and location of the employer. Wages are reported in spells (with a begin and end date for each wage level) and in theory we could construct a day-by-day wage history for each individual. To keep the dataset manageable, we extract wages for a single day, June 30, in each year. Prior to 1997, records for temporary workers were not collected in digital form. To ensure comparability before and after 1997, we focus on workers identified in the IMSS data as permanent, defined as having a written contract of indefinite duration.

We select ages 16-65. To maintain consistency across years, we impose the lowest real value of the IMSS topcode for wage reporting (which occurred in 1991) in all years. We drop establishments with a single insured worker, since these are likely to be self-employed workers. In the interests of comparability with the ENEU household data, we include only the metropolitan areas included in the ENEU samples (described below). We also focus on sectors for which we are confident that IMSS is the only available formal-sector social insurance program: manufacturing, construction, and retail/hotel/restaurants. Other broad sectors contain a substantial share of public employees, who are typically covered by a separate system. ${ }^{28}$ We focus primarily on men, for the reasons discussed in Section 2 above. (Results for women are reported in Appendix D (online).) When individuals have more than one job, we select the highest wage job. We refer to the sample selected following these criteria as our IMSS baseline sample. Further details on sample selection and data processing in Appendix C (online).

\footnotetext{
${ }^{27}$ The data have been used in several previous papers, including Castellanos, Garcia-Verdu, and Kaplan (2004), and Frías, Kaplan, and Verhoogen (2009).

${ }^{28}$ We focus on manufacturing, construction, and retail/hotel/restaurants in part so that we can be confident that respondents to the household survey are not mistaking coverage under the public-sector system for IMSS coverage.
} 
The household data we use are from the Encuesta Nacional de Empleo Urbano (ENEU) [National Urban Employment Survey], a household survey modeled on the Current Population Survey (CPS) in the United States, collected by the Instituto Nacional de Estadísticas y Geografía (INEGI), the Mexican statistical agency. The original ENEU sample, beginning in 1987, focused on the 16 largest Mexican metropolitan areas; although the coverage expanded over time, to maximize the number of pre-reform years we focus on the original 16 areas. As in the IMSS data, we include male workers ages 16-65, focus on the second quarter of each year, exclude self-employed workers, impose the 1991 IMSS topcode in all years, and include only manufacturing, construction, and retail/hotels/restaurants. When individuals report having more than one job, we use the information only from their main job. All calculations below use the sampling weights provided by INEGI.

A very useful feature of the ENEU for our purposes is that it asks respondents whether they receive IMSS coverage as an employment benefit. Beginning in the third quarter of 1994, the ENEU also asked respondents whether they had a written contract of indefinite duration, the legal definition of a permanent employee used by IMSS. Hourly wages are calculated as monthly wages divided by 4.3 times hours worked in the previous week, and daily wages as 8 times hourly wages. The ENEU wage measures are based on respondents' reports of take-home pay, after social security taxes have been paid. They also exclude bonuses paid less frequently than monthly, and hence exclude the yearly aguinaldo bonus. The differences between the IMSS and the ENEU wage measures are discussed further in Appendix C (online).

Although the ENEU survey does not contain a firm identifier, it does ask respondents about the size of the firm at which he or she works. We use this information to generate a firm-size indicator taking on values $1-10,11-50,51-100,101-250$, or $250+$ employees. $^{29}$ In addition, we drop workers with reported daily wages below 30 pesos (in 2002 constant pesos, approximately US $\$ 3$, about 50 percent of the lowest legal minimum wage.) In principle, both the IMSS and the ENEU data are available over the 1987-2005 period. But there appear to be a number of data inconsistencies in the ENEU in 1987, the first year of the survey. In addition, the ENEU sampling scheme was redesigned in the third quarter of 2003. We therefore take as our study period 1988 - 2003 quarter 2.

Our goal in the preparation of the datasets is to construct samples in the IMSS and ENEU data that are as similar as possible. Table 2 presents summary statistics for the IMSS baseline sample and various ENEU samples for 1990 and 2000 (decennial population census years), for a set of variables that are common between the sources: daily (post-tax) wage, age, and share in large establishments (with more than 100 employees). ${ }^{30}$ Column 2 contains the "full" ENEU

\footnotetext{
${ }^{29}$ The survey allows for eight responses, 1, 2-5, 6-10, 11-15, 16-50, 51-100, 101-250 and 250+. To ensure that sample sizes within cells are sufficiently large, we create the five categories listed above.

${ }^{30}$ We focus on decennial population census years because (in unreported results) we have been able to validate the ENEU sample against the population censuses in those years.
} 
sample, containing all non-self-employed men satisfying the age and sector criteria. Comparing columns 3 and 4, we see that ENEU workers with IMSS coverage tend to be higher-wage and more likely to work in large establishments than workers without IMSS coverage. Column 5 contains the sample that in principle should be the best match for the IMSS baseline sample: ENEU workers who report receiving IMSS coverage and having a written contract of indefinite duration - that is, who satisfy the definition of "permanent" used by IMSS. The average wage for this ENEU sample is greater than for the IMSS baseline sample, consistent with our argument below that there is under-reporting of wages in the IMSS data. Because the contract-type variable is available only beginning in 1994, however, we have prohibitively few years of pre-reform data for this sample. Instead, we will focus hereafter on the Column 6 sample, ENEU workers who report receiving IMSS coverage and working full-time (i.e. at least 35 hours in the previous week), which can be defined consistently over the entire period. We refer to the Column 6 sample as our ENEU baseline sample.

It is important to recognize that there are a number of reasons why the IMSS and ENEU baseline samples may differ. Some temporary workers may work full-time, and some permanent workers may work part-time. Comparing Columns 5 and 6 in Table 2 for the year 2000, we see that average wages are significantly lower in the Column 6 sample; this is attributable to the facts that temporary full-time workers earn relatively low wages and that permanent part-time workers earn relatively high wages on average. It may also be that firms interpret "permanent" to mean something different from the legal definition (i.e written contract of indefinite duration) when reporting wages. In addition, patterns of non-response may differ between the IMSS and ENEU samples. It is well known, for instance, that richer households tend to be less likely to respond to income questions in household surveys (Groves and Couper, 1998). The weighted employment totals from the ENEU data in Columns 5 and 6 are below the IMSS totals in Column 1; this may in part reflect such non-response. ${ }^{31}$

To further explore the employment discrepancy, Figure 5 plots employment totals over the 1988-2003 period for the same samples as in Table 2. We see that over most of the period the number of workers in the IMSS sample is slightly greater than the numbers in any of the ENEU samples. In addition to non-response in the ENEU, this difference likely reflects that fact that the IMSS sample is based on place of work while the ENEU sample is based on place of residence; hence people who commute in to metropolitan areas are included in the IMSS data but not in the ENEU. Another possibility is that some respondents are unaware that they receive IMSS coverage from their employer, or believe that they are covered by the public-sector social security agency (known by the acronym ISSSTE) when in fact they are covered by IMSS. For our purposes, however, the most important lesson of the figure is that there does not appear to have been a

\footnotetext{
${ }^{31}$ Note, however, that non-response by richer households will tend to lead us to understate evasion, making it more difficult for us to pick up statistically significant differences in cross-section.
} 
large change over time in the extent of the employment discrepancy between the IMSS and ENEU samples in response to the pension reform. Nor does it appear that there was a significant large inflow to (or outflow from) formal employment in response to the pension reform.

To further explore the comparability of the IMSS and ENEU samples, Table 3 compares the distributions in each sample across two dimensions that will be important in our analysis, age and firm size. In order to ensure that we have sufficient sample size in the ENEU to calculate the evasion measures below, we group individuals into five age categories (ages 16-25, 26-35, 36-45, 46-55, 56-65). Comparing the rightmost columns for the two panels, which indicate the share of employment in each firm size category as a share of total employment, it appears that firm sizes in the ENEU are skewed slightly away from the smallest and toward the largest size category (although there is non-monotonicity at intermediate sizes.) This may be because respondents in the household survey do not distinguish between employees directly hired by their employer and sub-contracted employees, or simply that respondents systematically overestimate employment. It may also be that firms under-report employment to IMSS, although the patterns of employment differences in Table 2 and Figure 5 tend to cast doubt on this interpretation. The distributions of employment across age groups conditional on a particular firm-size category also reveal some differences. In general, in the ENEU it appears that employment in smaller firms is shifted a bit toward younger workers relative to the IMSS (with the opposite shift among larger firms). But the overall distributions across age categories (in the "all firm sizes" rows) appear to be fairly similar.

Overall, although the IMSS and ENEU samples are not identical, and caution is warranted in interpreting cross-sectional differences between them, the samples appear to be sufficiently similar that it is not unreasonable to use the wage discrepancy between them as a measure of evasion. We also emphasize that any differences between the samples that are constant over time will be differenced out in our difference-in-differences procedure.

\section{Cross-Sectional Patterns of Compliance}

In this section, we consider cross-sectional differences in wage distributions between the IMSS and ENEU baseline samples in the pre-reform period. We focus on 1990, a decennial population census year. We begin with simple histograms to illustrate the main patterns. Figure 6 plots simple histograms of pre-tax daily wages from the IMSS data (gray bars) and daily take-home wages from the ENEU data (bars with black borders and no fill color), using bins that are five pesos wide. The three vertical lines at left indicate the three regional minimum wages in Mexico, with the rightmost corresponding to the minimum wage in Mexico City. For visual clarity, Figure 7 plots similar histograms using the same samples but using only observations below 200 pesos (approximately US\$20), with bins two pesos wide. The pattern is clear: the IMSS distribution lies 
largely to the left of the ENEU distribution ${ }^{32}$ and there is bunching in the IMSS sample slightly above the three minimum wages. These bunches correspond to 104.5 percent of the minimum wages in each zone - the minimum reports to IMSS that did not incur penalties. Note that the IMSS distribution would be even further to the left if we plotted the post-tax IMSS wage (which is more directly comparable to the ENEU wage). The bunching and shift to the left of the distribution is precisely what one would have expected, given that, for most workers, social security benefits were insensitive to reported wages, as long as their firms made the minimum contributions on their behalf.

A key empirical implication of our model, as well as of the previous theoretical work by Kleven et al. (2009), is that there is less evasion in larger firms. Figure 8 presents figures similar to Figure 7 (focused on daily wages below 200 pesos), separately for five firm sizes. Caution is warranted in interpreting these figures, since observed establishment size in the IMSS data may itself be affected by firms' compliance decisions. Subject to this caveat, it appears that there is less bunching on the minimum allowable wage reports at larger firm sizes, suggesting greater compliance. Even in establishments with 250 workers or more, however, there is evidence of bunching at the minimum allowable wage report, suggesting some under-reporting even in quite large firms. The observed heterogeneity in compliance by firm size is consistent with the view of Hsieh and Klenow (2014) and Hsieh and Olken (2014) that the payroll-tax burden falls more heavily on larger firms, and this may part of the explanation for the disproportionately large number of small firms in Mexico and other developing countries.

To quantify the extent of non-compliance, we construct three measures of evasion. Recall from equation (1) that the unreported wage is the difference between the worker's net wage and the post-tax wage reported by the firm: $w_{u}=w_{n e t}-(1-\tau) w_{r}$. As noted above, the ENEU survey asks individuals their take-home wage, which corresponds to $w_{n e t}$, and the raw IMSS administrative records contain the reported wage, $w_{r}$. We know the social security tax scheduled in each year, discussed in Section 2, and hence can calculate the IMSS post-tax wage. The ENEU data do not contain firm identifiers, but we can construct an estimate of $w_{u}$ at the level of cells defined by metropolitan area, sector, firm size categories and/or age groups.

At the cell level, our first measure of evasion is the log median ENEU take-home wage minus the log median IMSS post-tax wage. Our second measure is defined analogously, using the mean instead of the median. We refer to these as the "wage gap (medians)" and the "wage gap (means)," respectively.

Our third measure of evasion is an estimate of the excess mass at the left tail of the IMSS wage distribution. Figure 9 illustrates the calculation. The dotted (blue) curve is a non-parametric

\footnotetext{
${ }^{32}$ The exception to this generalization is at the far right tail. In Figure 6, we see that there is relatively more weight at the topcode in the IMSS sample; there is also slightly more weight at high wage values just below the topcode. This appears to reflect non-response by high-income households in the ENEU - a common pattern in household surveys, as mentioned above.
} 
estimate of the ENEU distribution, the one that underlies the hollow-rectangle histogram in Figure 6. The solid (red) curve is a non-parametric estimate of the post-tax IMSS distribution. The ENEU take-home wage and the IMSS post-tax wage are an "apples-to-apples" comparison; in the absence of evasion, they should coincide. We calculate the excess mass as the fraction of the IMSS sample minus the fraction of the ENEU sample to the left of $15^{\text {th }}$ percentile of the ENEU distribution. ${ }^{33}$ Intuitively, our excess mass measure reflects the share of the sample that has to be moved from right to left across the vertical line in order to transform the dotted (blue) distribution into the solid (red) distribution. ${ }^{34}$

The level of aggregation is an important issue when constructing these evasion measures. Although sample size is not a severe constraint in the IMSS administrative records, the ENEU contains on the order of 10,000-14,000 raw observations on male full-time workers in each quarter in the country as a whole. When we divide these by age group, metropolitan area, firm-size category and sector, cell sizes in the ENEU can become prohibitively small. We cannot avoid doing some aggregation. As discussed above, we focus on five age categories and five firm size categories. We also aggregate four-digit industries into three broad sectors: manufacturing, construction, and retail/services. In addition, when constructing the evasion measures, we pool all four quarters within a given year in the ENEU data. ${ }^{35}$ In this section, we present cross-sectional statistics using the measures of evasion calculated at the metro area/sector/firm size category/age group level. Below we will conduct the analyses at higher levels of aggregation, as appropriate to the questions being investigated.

Table 4 reports simple cross-sectional regressions of our three evasion measures on age-group, firm-size and sector indicators in 1990. For each evasion measure, we report simple regressions on a set of age-group or firm-size indicators without controls (Columns 1-2, 4-5, and 7-8) and then a regression including sector indicators and metro-area indicators (Columns 3, 6, and 9). For age groups, there is clear evidence that evasion is higher on average for the youngest age group, ages 16-25 (the omitted category), perhaps not surprisingly, since the youngest workers tend to

\footnotetext{
${ }^{33}$ In choosing the critical value for the excess mass calculation, we face a trade-off. On one hand, we want a value that is clearly to the right of the region of bunching in the IMSS data. On the other hand, we do not want a value so far to the right that the measure misses under-reporting behavior. (If, for instance, the under-reporting of wages occurs only for workers below the median, using the $50^{\text {th }}$ percentile as the critical value will completely miss the under-reporting behavior.) The results using other higher percentiles than the $15^{\text {th }}$ are qualitatively similar, although slightly weaker in some years.

${ }^{34}$ This excess mass measure differs from other excess mass measures that have been used in the literature, for instance by Saez (2010), Chetty, Friedman, Olsen, and Pistaferri (2011), and Kleven and Waseem (2013), in two ways. First, in our setting we do not have to construct a counterfactual distribution, requiring assumptions about how individuals in the region of bunching are distributed in the counterfactual; here effectively we observe the counterfactual distribution in the ENEU household data. Second, it is common to scale the excess mass by the density of the counterfactual distribution in the region of bunching; in our setting at the left tail the density of the ENEU wage distribution is near zero, and dividing by this density might introduce significant errors, so we do not re-scale.

${ }^{35}$ Because the survey follows households for five quarters, observations in different quarters are not independent, but our econometric tests do not require an independence assumption.
} 
have lower labor-force attachment and higher mobility across jobs. The differences in coefficients among the over-25 age groups are generally not significantly different from one another. For firm size, the general pattern is that evasion is declining in employment, consistent with the pattern in the raw histograms in Figure 8. There appears to be some non-monotonicity in the relationship between evasion and firm size for the intermediate size categories (51-100 and 101-250 employees), but it appears robust that evasion is lower in 11-50 employee firms than in 1-10 employee firms (the omitted category), and lower still in 250+ employee firms. The estimates are largely unaffected by controlling for age group, metro area, and sector, which suggests that the pattern we observed in the raw data in Figure 8 is not due to differing age or metro area composition in different firm size categories. Finally, evasion follows a consistent pattern across broad sectors, with construction displaying the greatest extent of evasion, followed by manufacturing, followed by retail/services.

Before moving on to the difference-in-difference analysis, we briefly examine the wage distributions for two sets of manufacturing establishments that can be linked to plant-level datasets collected by INEGI, the Mexican statistical agency. An important insight from the taxation literature is that the larger the number of reports the tax authorities receive on firms' tax liabilities, the more difficult it is for firms to evade (Kopczuk and Slemrod, 2006). ${ }^{36}$ The plant-level datasets from INEGI do not contain individual-level wage information on the full distribution of wages, but it is nevertheless instructive to consider the reports of covered plants to the social security agency. Figure 10 plots the IMSS wage distribution for workers in manufacturing establishments that also appear in the main Mexican longitudinal plant panel, the Encuesta Industrial Anual (EIA) [Annual Industrial Survey], which excludes assembly-for-export maquiladora plants. ${ }^{37}$ There is little evidence of bunching at the minimum allowable wage values, suggesting relatively little underreporting of wages. The EIA sample consists mainly of plants with more than 100 employees, and we saw above that larger plants are less likely to under-report. But the EIA plants display less bunching even than plants in the 100-250 and >250 employees categories in Figure 8. For the sake of completeness, Figure 11 plots the IMSS wage distribution for workers in assembly-for-export maquiladora plants, on which monthly statistics are reported in the Estadísticas Mensuales de la Industria Maquiladora de Exportación (EMIME) [Monthly Statistics on Export Maquiladora Industry]. Maquiladoras captured in the EMIME generally tend to have lower wages than the non-maquiladoras captured in the EIA. Although there is significant bunching at the minimum allowable wage values, it is difficult to determine whether this reflects under-reporting or simply the fact that many maquiladoras pay wages at or near the minimum.

\footnotetext{
${ }^{36}$ In fact, the INEGI does not share plant-level information collected in INEGI surveys with the Mexican tax authorities. It is not clear that plants are aware of this, however, and hence being required to report to INEGI may lead firm to report more accurately to the tax authorities.

${ }^{37}$ The links between establishments in the IMSS data and the EIA were constructed and first exploited in Frías, Kaplan, and Verhoogen (2009); see that paper for details of the linking.
} 


\section{Effect of Pension Reform on Compliance}

We now consider how evasion varied over time by age group in response to the pension reform. ${ }^{38} \mathrm{~A}$ simple set of graphs illustrates our main finding. Figure 12 plots non-parametric estimates of the male wage distributions, similar to those in Figure 9 but for wages levels below 200 pesos/day, by age group, for three years, 1990, 1997, and $2003 .{ }^{39}$ (The solid red distribution is from the IMSS administrative records, the dotted blue from the ENEU household data, as in Figure 9.) Each column of graphs corresponds to an age group (indicated in the x-axis titles) and each row to a year. The key empirical pattern is illustrated by the contrast between the first column, corresponding to ages 16-25, and the last column, corresponding to ages 56-65. There is a clear decline in bunching and shift to the right of the IMSS distribution for the youngest age group. For the oldest age group, there is little evident decline in bunching or shift to the right in the IMSS distribution.

It is important to note that there were a number of macroeconomic events that affected wages over our period and these may have affected the IMSS and ENEU distributions differently. In particular, the peso crisis of late 1994 and 1995 lead to a decline in average real wages of approximately 25 percent. It took several years for wages to regain their 1994 levels in real terms. Given that wages for many individuals were already at the minimum in the IMSS distribution (and hence could not decline further), one would expect the macro shock to generate more movement to the left of the ENEU distributions. This difference will generate differences in our measures of evasion over time, but we would like to net out these changes and not use them in estimating the response of evasion to the pension reform.

Another possible concern with Figure 12 is that the differential changes by age group may reflect shocks to local labor markets which differ in their age composition. Given, for instance, that the workforces in cities along Mexico's border with the U.S. tend to be younger on average that those in the Center and South of the country, and that wages in the North dropped less than those in the Center or South in real terms with the crisis (partly because of the expansion of maquiladora in-bond assembly plants in the North), one might see apparent differential movements in the IMSS and ENEU distributions due to local labor-market shocks, rather than changes in evasion choices due to the pension reform.

To address both of the above concerns, we remove any changes in wage gaps that are common

\footnotetext{
${ }^{38}$ A possible alternative strategy would be to compare workers of different wage levels, since, as Table 1 indicates, higher-wage workers had a higher expectation of using the personal retirement account and hence arguably a greater incentive to improve compliance. But our argument is that wage reports in the IMSS respond endogenously to reporting incentives. It is not clear how to construct comparable samples in the IMSS and ENEU data for workers of different wage levels. For this reason, we focus on a clearly pre-determined variable, age.

${ }^{39}$ We present non-parametric density estimates, rather than histograms, because they are easier to interpret visually. Histograms would convey a qualitatively similar message. The ENEU distributions reflect some heaping at round numbers and multiples of the minimum wage. It is also important to note that the ENEU sample sizes are not enormous, particularly when separating by age group. (Refer for instance to Tables 2 and 3.)
} 
across age groups in a given metro area-year. That is, we calculate the wage gap (medians) measure at the age group/metro area/year level, regress it on a full set of metro area-year indicators, recover the residuals and average them at the age group-year level. Figure 13 plots these averages. It is important to be clear that, given that we have netted out any changes in wage gaps common to all age groups within metro-years, the levels of the wage gap in this figure sum to zero in each year. Any changes in the wage gap for a given age group are relative to changes for the other age groups; they do not reflect changes in the absolute levels of the wage gaps. There are two main points to notice in Figure 13. First, as we saw in Table 4, evasion is highest for the youngest age group. Second, and more importantly, the gaps for the younger age groups declined relative to the oldest group, 56-65 (or, if you prefer, the gap for the oldest age group, 56-65, increased relative to the others.) To the extent that there is another group that appears to have seen a relative increase, it is the second-oldest age group, 46-55. For the oldest age group, it appears that the relative increase may have begun between the $2^{\text {nd }}$ quarter of 1995 and the $2^{\text {nd }}$ quarter of 1996, which corresponds to the time of passage of the law; there was significant discussion of the pension reform in the popular press around the time of passage, and it is possible that employees anticipated the effects of the reform and started paying attention to under-reporting even before the reform took effect in July 1997. However, to be conservative, in our regression analysis below we will take July 1, 1997 as the date of the reform. Even using this more conservative choice, it appears that there was a differential increase in evasion for the oldest two age groups relative to the younger ones.

Table 5 reports regressions that capture the pattern illustrated in Figure 13. Motivated by the figure, we look for a divergence in the time-path of evasion for the younger groups relative to the oldest group. We interact an indicator for being in one of the four younger groups (i.e. age $<=55$ ) with year effects for each year over the 1988-2003 period, omitting the interaction with 1997, the year the reform was implemented. We control flexibly for metro area-year effects and age groupmetro area effects. The key finding is that, across the three measures of evasion, we see little evidence of a differential pre-trend but robust evidence of a relative decrease in evasion for the younger age groups following the passage of the reform. The wage gap (medians) measure takes a bit longer than the wage gap (means) measure to show statistically significant relative decline, but the fact that we see a similar pattern across the three measures is reassuring. ${ }^{40}$ The choice to focus on the younger four age groups relative to the oldest group is not crucial; Appendix Table A6 reports regressions similar to those in Table 5, but with using an indicator for being in the

\footnotetext{
${ }^{40}$ The wage gap (means) measure is sensitive to the change in IMSS reporting requirements in 1991 (as mentioned in footnote 22, prior to 1991 employers were allowed to report wages below the legal minimum wage; after 1991, they were not), and for this reason we prefer the wage gap (medians) measure, although it appears to be less sensitive to the policy change. Also, the results for the excess mass measure when using different critical values are slightly weaker when using critical values above the $15^{\text {th }}$ percentile. This is particularly true in 2003 , a year in which we have consistent ENEU data only for the first two quarter. But for all critical values between the $10^{t h}$ and $35^{t h}$ percentiles the excess mass measures show a significant differential change by 2001-2002.
} 
three younger groups rather than four. Although we lose significance for the excess mass measure in 2003 (a year in which we have less data in the ENEU), the results are generally consistent with Table 5. Overall, the results are supportive of our second main theoretical implication: evasion for younger age groups declined relatively more than evasion for older groups.

The results for our evasion measures do not seem to be driven by discrepancies in the reporting of employment in the two data sources. Table 6 reports regressions similar to those in Table 5, but where the outcome variable is the difference in log employment - what we can call the "employment gap" - between the ENEU and IMSS baseline samples within an age group-metro area cell, rather than one of the evasion measures. There is no evidence of a differential change in the employment gap for older workers in response to the reform. ${ }^{41}$

To conclude this section, we briefly consider the incidence of the reform on market-level net wages, using the ENEU household survey alone. Table 7 reports specifications similar to those in Table 5, where the outcome is the log net wage reported on the ENEU survey, and we are able to control flexibly for individual characteristics. Column 1 includes just age-group and metro area-year effects, then moving across the columns we add sets of dummy variables for schooling categories, marital status, occupation, industry and firm size. The consistent message is that there is no systematic differential effect of the reform on net wages of the oldest age group. While this non-result may appear surprising, it is consistent with recent evidence from other countries on the effects of tax reforms on take-home wages. For instance, Saez, Matsaganis, and Tsakloglou (2012) find little evidence of differences in take-home pay for workers of different cohorts facing different payroll-tax rates. The authors speculate that institutional factors such as fairness norms may constrain firms' ability to offer different wages to otherwise similar workers facing different effective payroll tax rates. Such factors may also be present in Mexico and may similarly prevent firms from offering different take-home wages to different age groups. Also, as discussed briefly in Section 3 and in more detail in Appendix B, in our theoretical framework the relationship between the pension reform and the net wage is ambiguous, even without such institutional factors. In short, based both on prior empirical work and on our model, it is not clear that we should have expected to find a differential effect of the pension reform on take-home wages.

\section{Conclusion}

Improving firms' compliance with tax regulations is a first-order policy issue in many developing countries. Much of the development debate has focused on how to induce firms to register with tax authorities in the first place — what we might call the extensive margin of non-compliance. In

\footnotetext{
${ }^{41}$ Note that the employment gap here captures discrepancies in the number of workers reported to the IMSS system and the number who report on the household survey that they receive IMSS coverage; it does not capture changes in the propensity of firms to offer formal (i.e. covered by IMSS) employment. As mentioned above, we leave the investigation of the effects of the reform on the informal/formal employment margin for future work.
} 
this paper, we have shown that under-reporting of wages among firms that are already registered - non-compliance on an intensive margin - is also substantial and responds to incentives and the availability of information in the social security system. Third-party reporting of employees' wages by employers is no guarantee of accurate reporting in a low-enforcement context like Mexico.

The results suggest that providing incentives to workers to ensure accurate reporting, as well as information about firms' reports, should be a consideration in the design of social-insurance systems. Conceptually, our theoretical model suggests that an increase in such incentives and a commensurate reduction of payroll taxes should have equivalent effects on evasion, other things equal. But the effects on government revenues are decidedly non-equivalent. If the policy goal is to increase the fiscal capacity of the state, it appears that the tying benefits more closely to wage reports may be the preferable option.

A number of interesting questions remain open. One is to what extent workers are aware of under-reporting by their employers and, relatedly, to what extent the effects of the pension reform we observe are due to the change in incentives versus the change in information. It seems unlikely that the results we observe could be due solely to the increased availability of information postreform; if benefits had remained truly insensitive to wage reports, then workers would have had no reason to act on the information once they received it. ${ }^{42}$ But it remains possible that there was an important interaction between the change in incentives and the change in information. Separating the two effects definitively will require a research design in which incentives vary separately from costs of information.

Another important open question is whether increased pressure on firms to report accurately (which increases compliance on the intensive margin) induces more firms to remain informal (reduces compliance on the extensive margin). Because of the nature of the IMSS data, we are not able to observe firms as they move from formality to informality or vice-versa. But clearly a full accounting of the costs and benefits of policies to increase intensive-margin compliance will have to take such a response into account.

\section{References}

Aguila, E. (2011): "Personal Retirement Accounts and Saving," American Economic Journal: Economic Policy, 3(4), 1-24.

Andreoni, J., B. Erard, And J. Feinstein (1998): "Tax Compliance," Journal of Economic Literature, $36(2), 818-860$.

Bailey, C., And J. Turner (2001): "Strategies to Reduce Contribution Evasion in Social Security Financing," World Development, 29(2), 385-393.

BÉrgolo, M., ANd G. Cruces (2012): "Work and Tax Evasion Incentive Effects of Social Insurance Pro-

\footnotetext{
${ }^{42}$ Relatedly, a reduction of the cost of acquiring information about firms' reports would not be expected to have an effect, as long as the cost remains positive, as workers would not be willing to pay even an $\varepsilon$ cost to acquire it.
} 
grams: Evidence from an Employment Based Benefit Extension," Unpub. paper, CEDLAS, Universidad Nacional de la Plata.

Besley, T., And T. Persson (2013): "Taxation and Development," in Handbook of Public Economics, vol. 5, ed. by A. Auerbach, R. Chetty, M. Feldstein, and E. Saez. Elsevier.

Best, M. C. (2014): "The Role of Firms in Workers' Earnings Responses to Taxes: Evidence from Pakistan," Unpub. paper, LSE.

Best, M. C., A. Brockmeyer, H. J. Kleven, J. Spinnewijn, and M. Waseem (forthcoming): "Production vs Revenue Efficiency with Limited Tax Capacity: Theory and Evidence from Pakistan," Forthcoming, textitJournal of Political Economy.

Braguinsky, S., S. Mityakov, And A. Liscovich (2010): "Direct Estimation of Hidden Earnings: Evidence from Administrative Data," Unpub. paper, Carnegie-Mellon University.

Burgess, R., And N. Stern (1993): "Taxation and Development," Journal of Economic Literature, $31(2)$, pp. $762-830$.

Castellanos, S., R. Garcia-Verdu, and D. Kaplan (2004): "Wage Rigidities in Mexico: Evidence from Social Security Records," Journal of Development Economics, 75(2), 507-33.

Chetty, R., J. N. Friedman, T. Olsen, and L. Pistaferri (2011): "Adjustment Costs, Firm Responses, and Micro vs. Macro Labor Supply Elasticities: Evidence from Danish Tax Records," The Quarterly Journal of Economics, 126(2), pp. 749-804.

Dabla-Norris, E., M. Gradstein, and G. Inchauste (2008): "What Causes Firms to Hide Output? The Determinants of Informality," Journal of Development Economics, 85(1-2), 1 - 27.

De Mel, S., D. J. McKenzie, And C. Woodruff (2012): "The Demand for, and Consequences of, Formalization among Informal Firms in Sri Lanka," NBER working paper no. 18019.

De Paula, A., And J. Scheinkman (2011): "The Informal Sector: An Equilibrium Model and Some Empirical Evidence from Brazil," Review of Income and Wealth, 57, S8-S26.

Dharmapala, D., J. Slemrod, and J. D. Wilson (2011): "Tax Policy and the Missing Middle: Optimal Tax Remittance with Firm-Level Administrative Costs," Journal of Public Economics, 95(9-10), 1036 1047.

Duarte, F., And J. Hastings (2010): "Fettered Consumers and Sophisticated Firms: Evidence from Mexico's Privatized Social Security Market," Unpub. paper, March.

Fisman, R., AND S.-J. Wei (2004): "Tax Rates and Tax Evasion: Evidence from Missing Imports in China," Journal of Political Economy, 112(2), 471-500.

Frías, J. A., D. S. Kaplan, and E. A. Verhoogen (2009): "Exports and Wage Premia: Evidence from Mexican Employer-Employee Data," Unpub. paper, Columbia University.

Galiani, S., And F. Weinschelbaum (forthcoming): "Modeling Informality Formally: Households and Firms," Forthcoming, Economic Inquiry.

Gordon, R., And W. Li (2009): "Tax Structures in Developing Countries: Many Puzzles and a Possible Explanation," Journal of Public Economics, 93(7-8), 855 - 866.

Gorodnichenko, Y., J. Martinez-Vazquez, And K. S. Peter (2009): "Myth and Reality of Flat Tax Reform: Micro Estimates of Tax Evasion Response and Welfare Effects in Russia.," Journal of Political Economy, 117(3), $504-554$.

Grandolini, G., And L. Cerda (1998): "The 1997 Pension Reform in Mexico," World Bank Policy Research Working Paper no. 1933.

Groves, R. M., And M. P. Couper (1998): Nonresponse in Household Interview Surveys. John Wiley \& Sons, New York.

Hsien, C.-T., And P. J. Klenow (2014): "The Life Cycle of Plants in India and Mexico," Quarterly Journal of Economics.

Hsien, C.-T., And B. A. Olken (2014): "The Missing "Missing Middle"," Journal of Economic Perspectives, 28(3), 89-108.

Hurst, E., G. Li, And B. Pugsley (2011): "Are Household Surveys Like Tax Forms? Evidence from Income Underreporting of the Self-Employed," Unpub. paper, University of Chicago.

IMF (2010): Government Finance Statistics Yearbook. International Monetary Fund Statistics Department. IMSS (2011): "Informe al Ejecutivo Federal y al Congreso de la Unión sobre la Situatión Financiera y los 
Riesgos del Instituto Mexicano del Seguro Social, 2010-2011," Mexico City, Mexico.

Internal Revenue Service (2006): "Updated Estimates of the Tax Year 2001 Individual Income Tax Underreporting Gap. Overview," Washington DC.

Keen, M., And B. Lockwood (2010): "The Value Added Tax: Its Causes and Consequences," Journal of Development Economics, 92(2), 138 - 151.

Khan, A., A. Khwaja, And B. Olken (2014): "Tax Farming Redux: Experimental Evidence on Performance Pay for Tax Collectors," NBER working paper no. 20627.

Kleven, H., M. Knudsen, C. T. Kreiner, S. Pedersen, and E. Saez (2011): "Unwilling or Unable to Cheat? Evidence from a Tax Audit Experiment in Denmark," Econometrica, 79, 651-692.

Kleven, H. J., C. T. Kreiner, And E. Saez (2009): "Why Can Modern Governments Tax So Much? An Agency Model of Firms as Fiscal Intermediaries," NBER working paper no. 15218.

Kleven, H. J., And M. Waseem (2013): "Using Notches to Uncover Optimization Frictions and Structural Elasticities: Theory and Evidence from Pakistan," The Quarterly Journal of Economics, 128(2), 669-723.

Kopczuk, W., And J. Slemrod (2006): "Putting Firms into Optimal Tax Theory," American Economic Review Papers 85 Proceedings, 96(2), 131-134.

Kumler, T., E. Verhoogen, and J. A. Frías (2012): "Enlisting Workers in Monitoring Firms: Payroll Tax Compliance in Mexico," Columbia University Department of Economics Discussion Paper no. 111207, June.

Lara-Ibarra, G. (2011): "Essays on the Determinants of Pension Savings and Retirement Management Decisions," Ph.D. thesis, University of Maryland.

Mao, J., L. Zhang, and J. Zhao (2013): "Social Security Taxation and Compliance: The Chinese Evidence," Unpub. paper, Tsinghua University.

Marion, J., And E. Muehlegger (2008): "Measuring Illegal Activity and the Effects of Regulatory Innovation: Tax Evasion and the Dyeing of Untaxed Diesel," Journal of Political Economy, 116(4), 633 -666 .

McKenzie, D., And Y. S. Sakho (2010): "Does It Pay Firms to Register for Taxes? The Impact of Formality on Firm Profitability.," Journal of Development Economics, 91(1), 15 - 24.

Melitz, M. J. (2003): "The Impact of Trade on Intra-Industry Reallocations and Aggregate Industry Productivity," Econometrica, 71(6), 1695-1725.

Naritomi, J. (2013): "Consumers as Tax Auditors," Unpub. paper, Harvard University.

Niehaus, P., and S. Sukhtankar (forthcoming): "Corruption Dynamics: the Golden Goose Effect," American Economic Journal: Economic Policy.

Nyland, C., R. Smyth, And C. Zhu (2006): "What Determines the Extent to Which Employers Will Comply with their Social Security Oblications? Evidence from Chinese Firm-level Data," Social Policy \& Administration, 40(2), 196-214.

OECD (1992): OECD Economic Surveys: Mexico 1992. OECD Publishing.

(1999): OECD Economic Surveys: Mexico 1999. OECD Publishing.

(2006): Tax Administration in OECD and Selection Non-OECD Countries: Comparative Information Series. OECD, Prepared by the Forum on Tax Administration, Centre for Tax Policy and Administration.

- (2011a): OECD Economic Surveys: Mexico 2011. OECD Publishing. (2011b): Revenue Statistics 1965-2010. OECD, Paris.

Olken, B. A. (2006): "Corruption and the Costs of Redistribution: Micro Evidence from Indonesia.," Journal of Public Economics, 90(4-5), 853 - 870.

Olken, B. A., And R. Pande (2012): "Corruption in Developing Countries.," Annual Review of Economics, 4(1), $479-509$.

Pissarides, C. A., And G. Weber (1989): “An Expenditure-Based Estimate of Britain's Black Economy," Journal of Public Economics, 39(1), 17 - 32.

Plumley, A. (2004): Overview of the Federal Tax Gap. Washington DC: U.S. Department of the Treasury, Internal Revenue Service, NHQ Office of Research.

Pomeranz, D. (2013): "No Taxation without Information: Deterrence and Self-Enforcement in the Value- 
Added Tax," Unpub. paper, Harvard Business School.

Rauch, J. E. (1991): "Modelling the Informal Sector Formally," Journal of Development Economics, $35(1), 33-47$.

Saez, E. (2010): "Do Taxpayers Bunch at Kink Points?," American Economic Journal: Economic Policy, $2(3), 180-212$.

Saez, E., M. Matsaganis, and P. Tsakloglou (2012): "Earnings Determination and Taxes: Evidence from a Cohort-Based Payroll Tax Reform in Greece.," Quarterly Journal of Economics, 127(1), 493 533.

Saez, E., J. B. Slemrod, And S. H. Giertz (2012): "The Elasticity of Taxable Income with Respect to Marginal Tax Rates: A Critical Review," Journal of Economic Literature, 50(1), 3-50.

Sales-Sarrapy, C., F. Solis-Soberon, and A. Villagomez-Amezcua (1996): "Pension System Reform: The Mexican Case," NBER Working Paper No. 5780.

Schneider, F., And D. H. Enste (2000): "Shadow Economies: Size, Causes, and Consequences," Journal of Economic Literature, 38(1), 77-114.

Slemrod, J. (2007): "Cheating Ourselves: The Economics of Tax Evasion," The Journal of Economic Perspectives, 21(1), 25-48.

Slemrod, J., And S. Yitzhaki (2002): "Tax Avoidance, Evasion and Administration," in Handbook of Public Economics, vol. 3, ed. by A. J. Auerbach, and M. Feldstein. Elsevier, Amsterdam.

Tonin, M. (2011): "Minimum Wage and Tax Evasion: Theory and Evidence," Journal of Public Economics, 95(11-12), $1635-1651$.

Yaniv, G. (1992): "Collaborated Employee-Employer Tax Evasion," Public Finance, 47(2), 312-321. 
Figure 1. Employer contributions

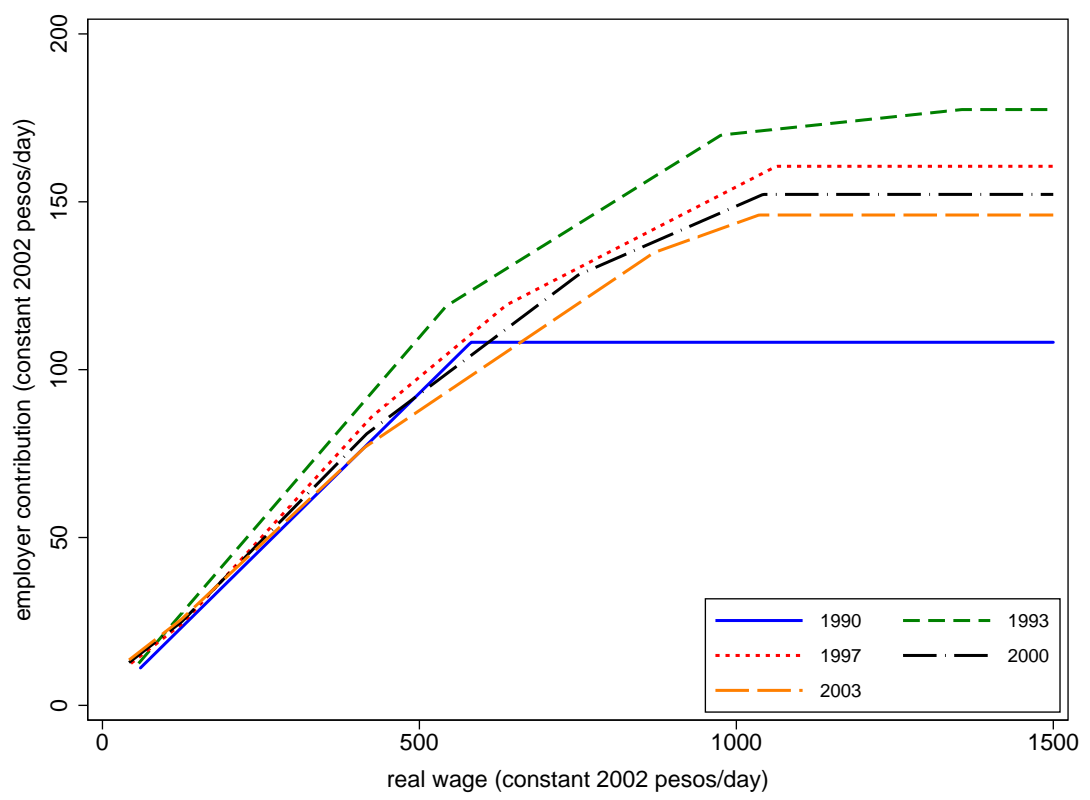

Notes: Variation in IMSS employer contribution rates at levels above 500 pesos/day are primarily due to changes in topcodes, which varied from 10 to 25 times the minimum wage in Mexico City over the period. Average 2002 exchange rate: 9.66 pesos/dollar.

\section{Figure 2. Employee contributions}

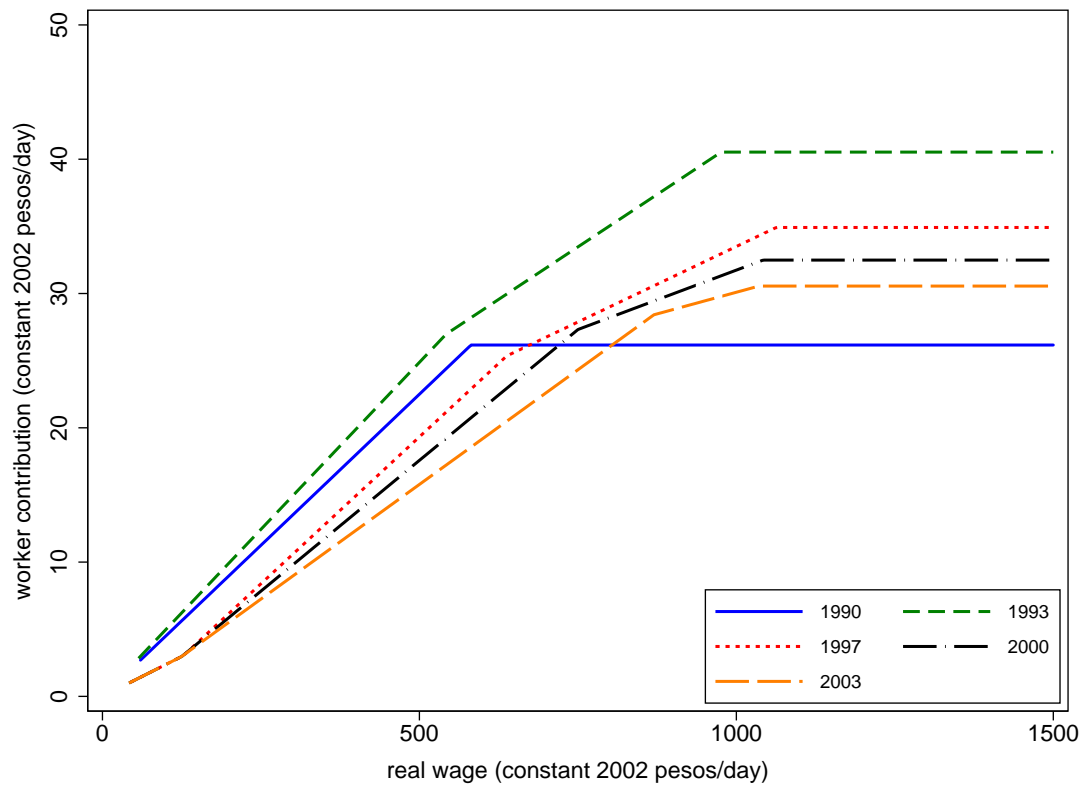

Notes: Variation in IMSS worker contribution rates at levels above 500 pesos/day are primarily due to changes in topcodes, which varied from 10 to 25 times the minimum wage in Mexico City over the period. Average 2002 exchange rate: 9.66 pesos/dollar. 
Figure 3. Pension values, selected years, men

A. Value of pension by wage, ages $60-65$
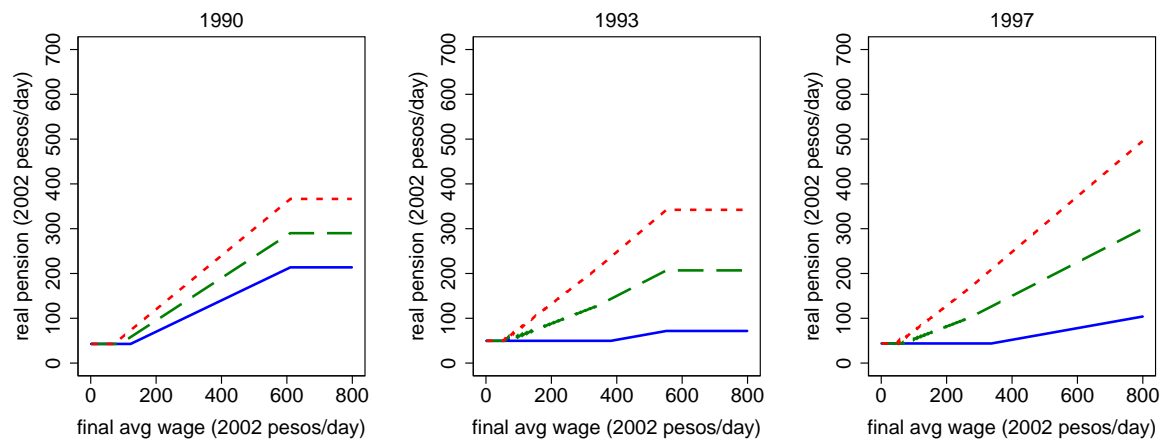

B. Value of pension by IMSS wage percentile, ages 60-65
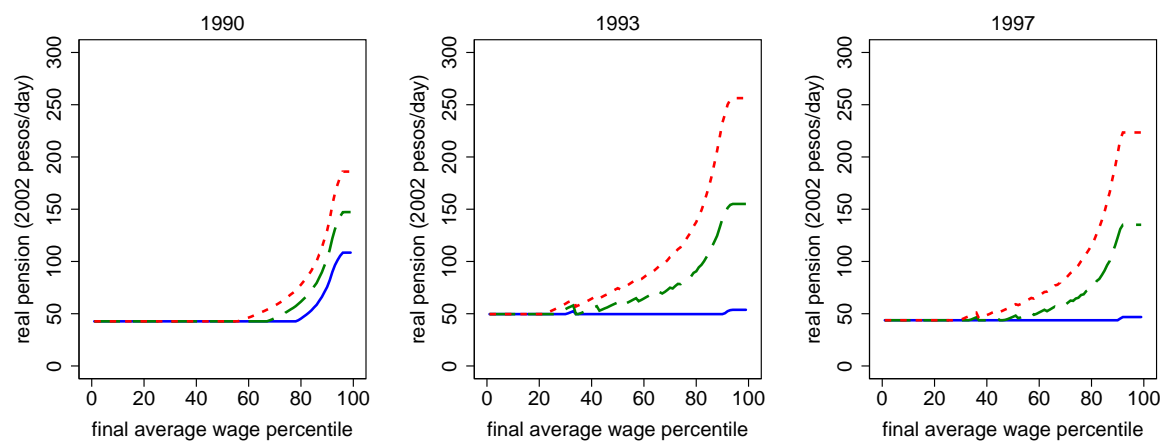

C. Value of pension by ENEU wage percentile, ages 60-65
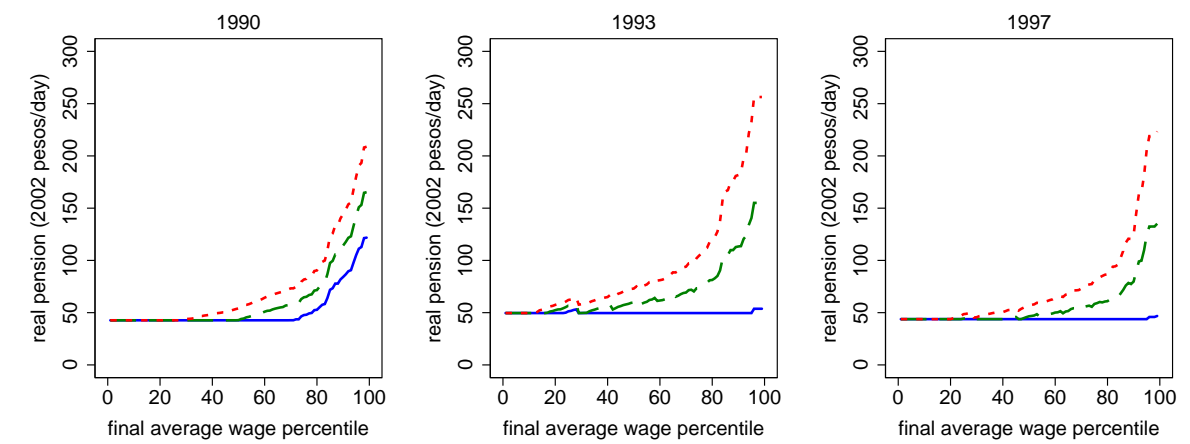

10 yrs conts. $\quad-\quad---20$ yrs conts.

[... . .... 30 yrs conts.

Notes: Final average wage (2002 pesos/day) is average nominal daily wage over five years prior to retirement, deflated to constant 2002 pesos. Figure indicates pension values for individuals with 10, 20 and 30 years of contributions to IMSS. In Panel B, we calculate the nominal wage at each quantile of the IMSS wage distribution for 60-65 year old men in each year and take the average for that quantile over the preceding five years. Panel $\mathrm{C}$ is constructed similarly using wage distributions from the ENEU baseline samples. See Section 4 for details of samples and Section 2.3 for details on pension benefits. Average 2002 exchange rate: 9.66 pesos/dollar. 
Perioso que comprente etst Essos de Cienta 01/MAY/2011 AL 31/AGO/2011

Madros

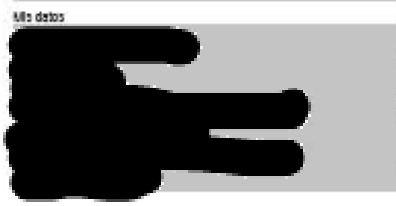

||||||||||||||||||||||||||||||||||

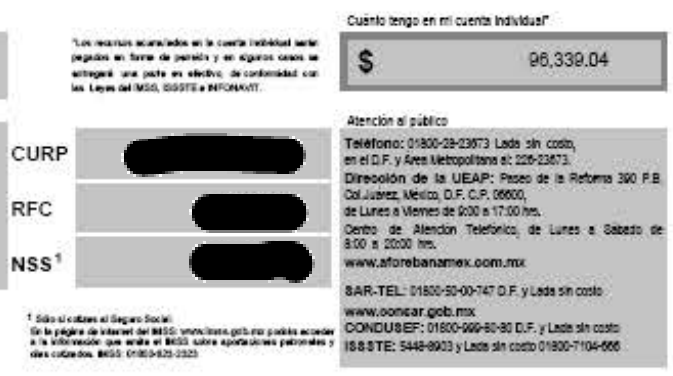

Cuarto ango en mi cuena haviduar

Asercion os sitico

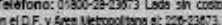

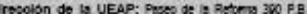

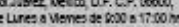

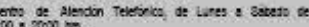

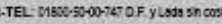

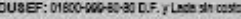

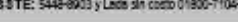

\section{i IMPORTANTE!}

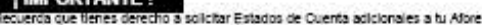

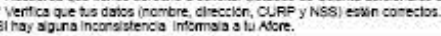

\begin{tabular}{|c|c|c|c|c|c|c|}
\hline \multicolumn{7}{|l|}{ Resumen genes: } \\
\hline constest & 89de anteror & Aparaskres: & setion & Fentrientios & Consones: & Sabsitrs \\
\hline M ahorro para el retiro & $40,085.88$ & $11,808,80$ & 0.00 & 280461 & 201.52 & 64.638 .48 \\
\hline \multirow[t]{2}{*}{ M ahomo voluntario } & 0.00 & 0.00 & 0.00 & 0.00 & 0.00 & 0.00 \\
\hline & \multicolumn{2}{|c|}{ Dato ementst } & \multicolumn{2}{|c|}{ Woutrientes } & \multicolumn{2}{|c|}{ 8:ass 4nal } \\
\hline M ahorro para la vivienda & \multicolumn{2}{|r|}{$32,168,18$} & \multicolumn{2}{|r|}{$8,261.37$} & \multicolumn{2}{|r|}{41.80068} \\
\hline TOTAL DE MI AHORRO & & & & & & $86,239.04$ \\
\hline
\end{tabular}

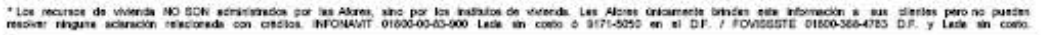

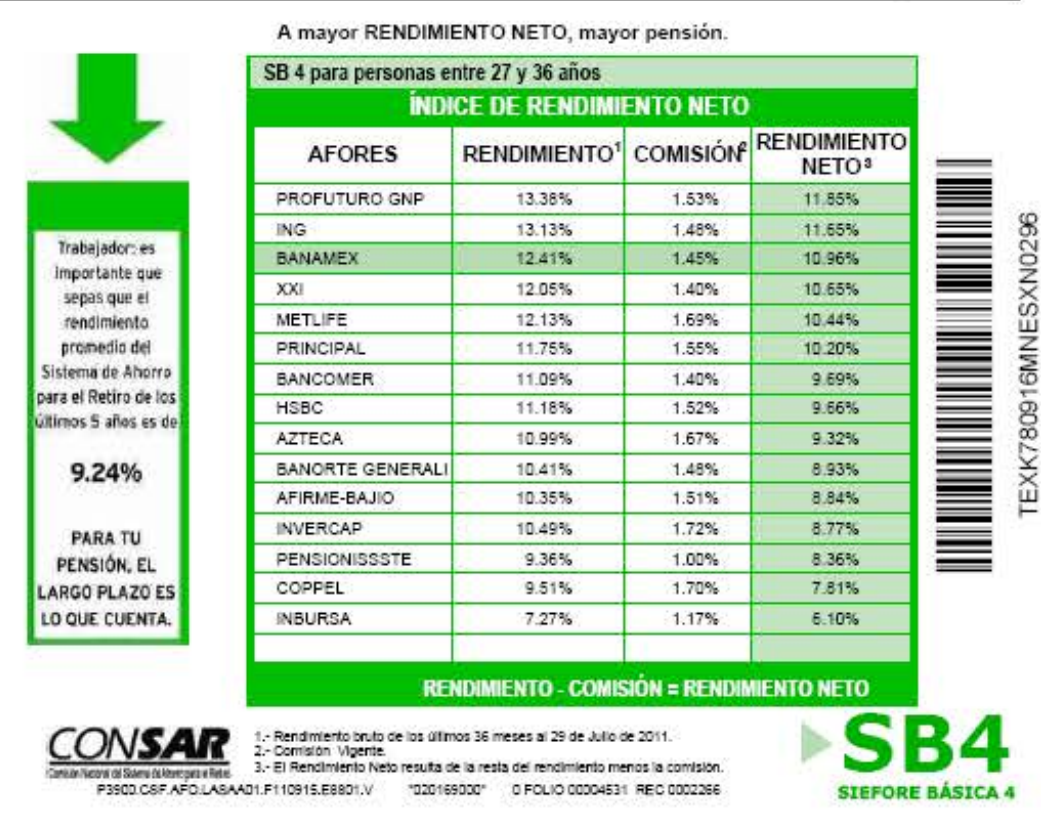

\section{pa.columbia... $\triangle \mathrm{C}$ :|tmpleompliance}

Notes: The box at top right ("Cuánto tengo en mi cuenta individual") reports total balance. The first row of boxes in the middle section ("Mi ahorro para el retiro") pertains to the retirement pension and reports previous balance ("Saldo anterior"), new contributions ("Aportaciones"), withdrawals ("Retiros"), interest earned ("Rendimientos"), AFORE commission charged ("Comisiones"), and final balance ("Saldo final"). The second and third rows in the middle section report balances in the individual's voluntary savings account and housing account. The bottom section reports 3-year returns and commissions for each AFORE, as well as the average 5-year net return (at left). 
Figure 5. Employment, IMSS admin. records vs. ENEU household data, men

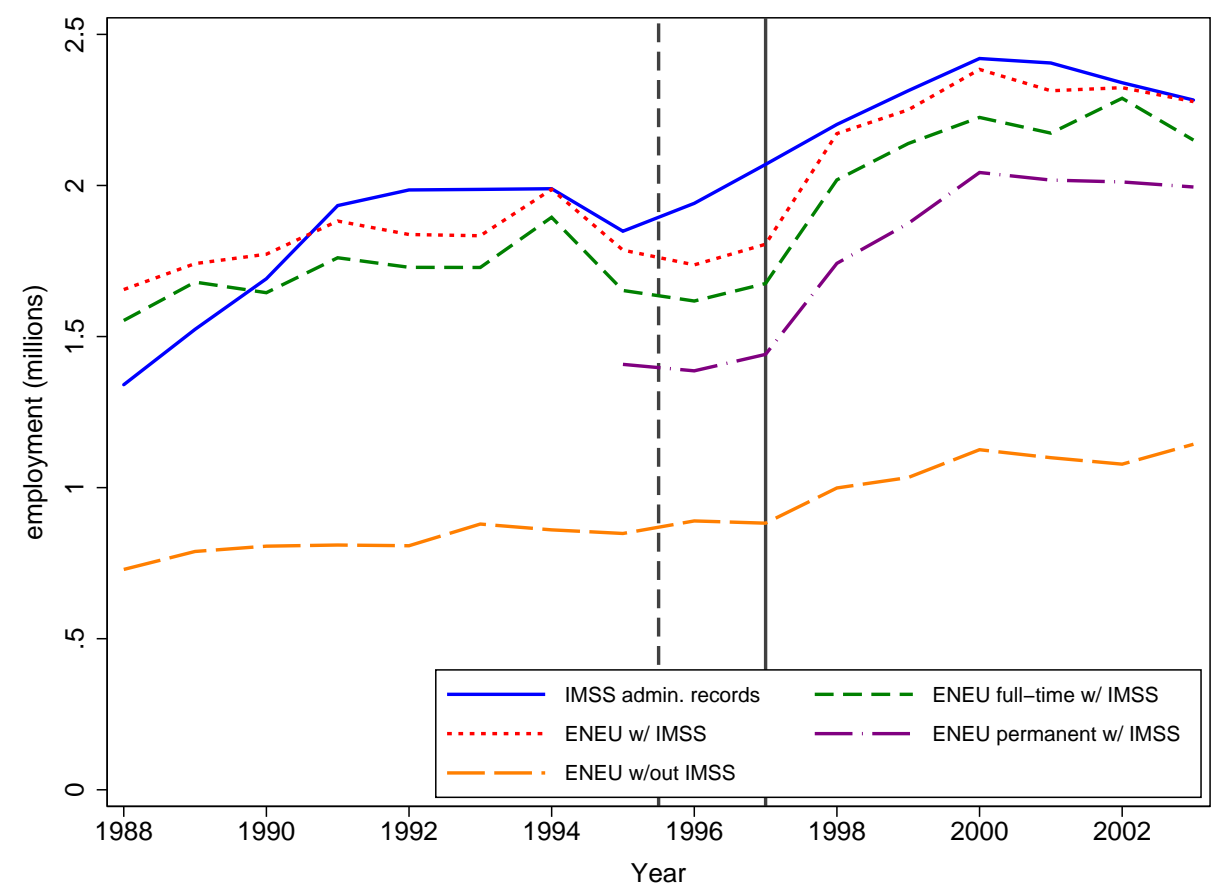

Notes: Samples are the same as those in Columns 1 and 3-6 of Table 2; refer to that table for details. ENEU totals are calculated using sampling weights. The dashed vertical line indicates the date the pension reform was passed by Congress (Dec. 21, 1995); the solid vertical line indicates the date the reform took effect (July 1, 1997). Observations correspond to the second quarter of each year. See Section 4 and Appendix C (online) for details of sample selection. 
Figure 6. Wage histograms, men, 1990

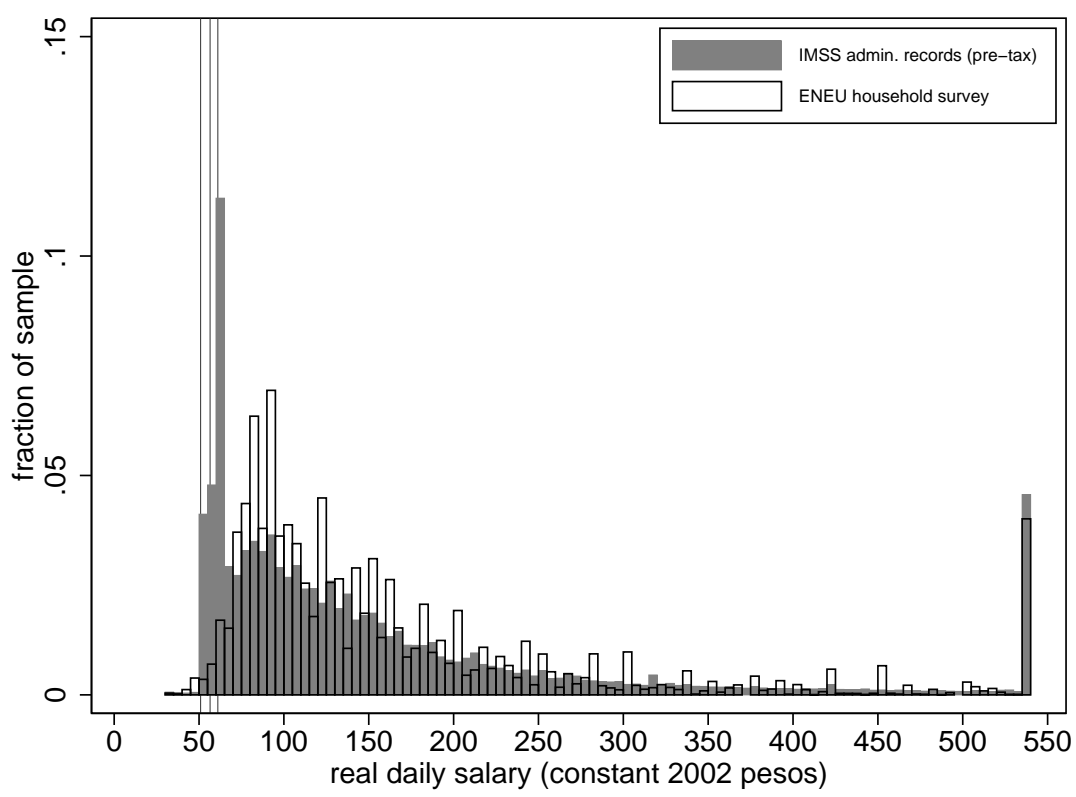

Notes: Samples are IMSS and ENEU "baseline" samples of men. Data in both samples are from second quarter of 1990. The IMSS wage is the real daily pre-tax reported wage from the IMSS administrative records. The ENEU wage is the real daily take-home wage reported to the ENEU household survey. Wages in 2002 pesos. Average 2002 exchange rate: 9.66 pesos/dollar. Vertical lines indicate minimum wages in the three minimum-wage zones in Mexico (A, B, C). Bins are 5 pesos wide. The rightmost bin captures all individuals with reported wages at or above the minimum IMSS topcode over the study period (from 1991). See Section 4 and Appendix C (online) for further details.

Figure 7. Wage histograms, men, 1990, low wage levels

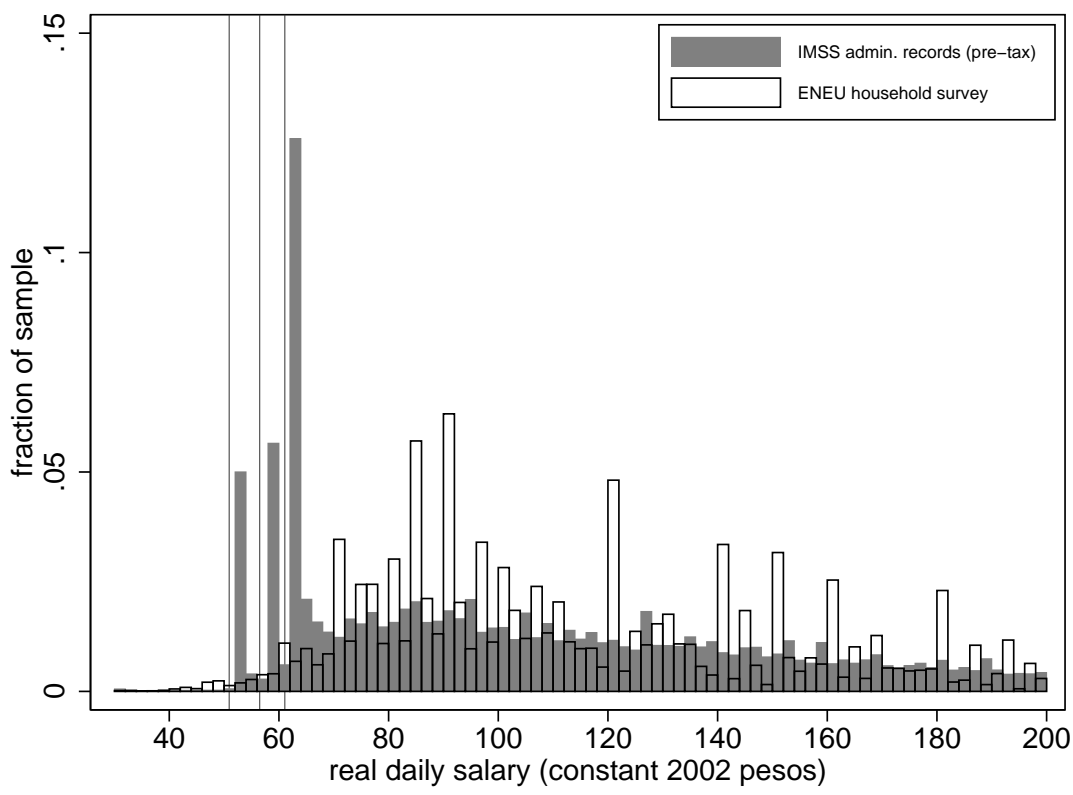

Notes: Histogram is similar to Figure 6 but only includes workers with wages less than 200 pesos/day (approx. $\$ 20 /$ day) in constant 2002 pesos. Bins are 2 pesos wide. 
Figure 8. Wage histograms by firm size, men, 1990, low wage levels
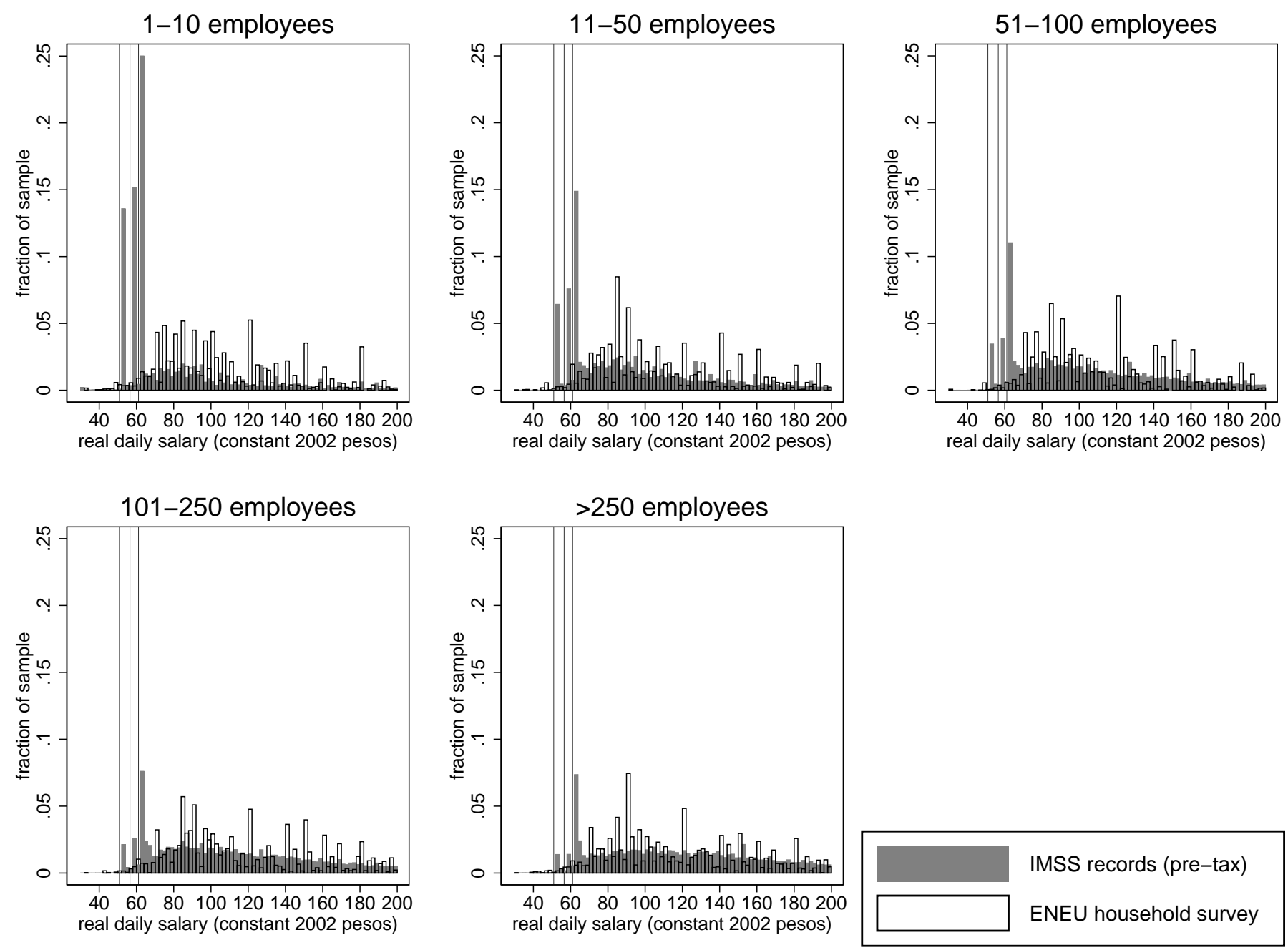

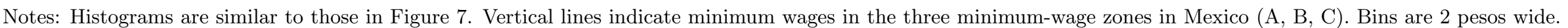
Average 2002 exchange rate: 9.66 pesos/dollar. See Section 4 and Appendix C (online) for further details. 


\section{Figure 9. Excess mass calculation}

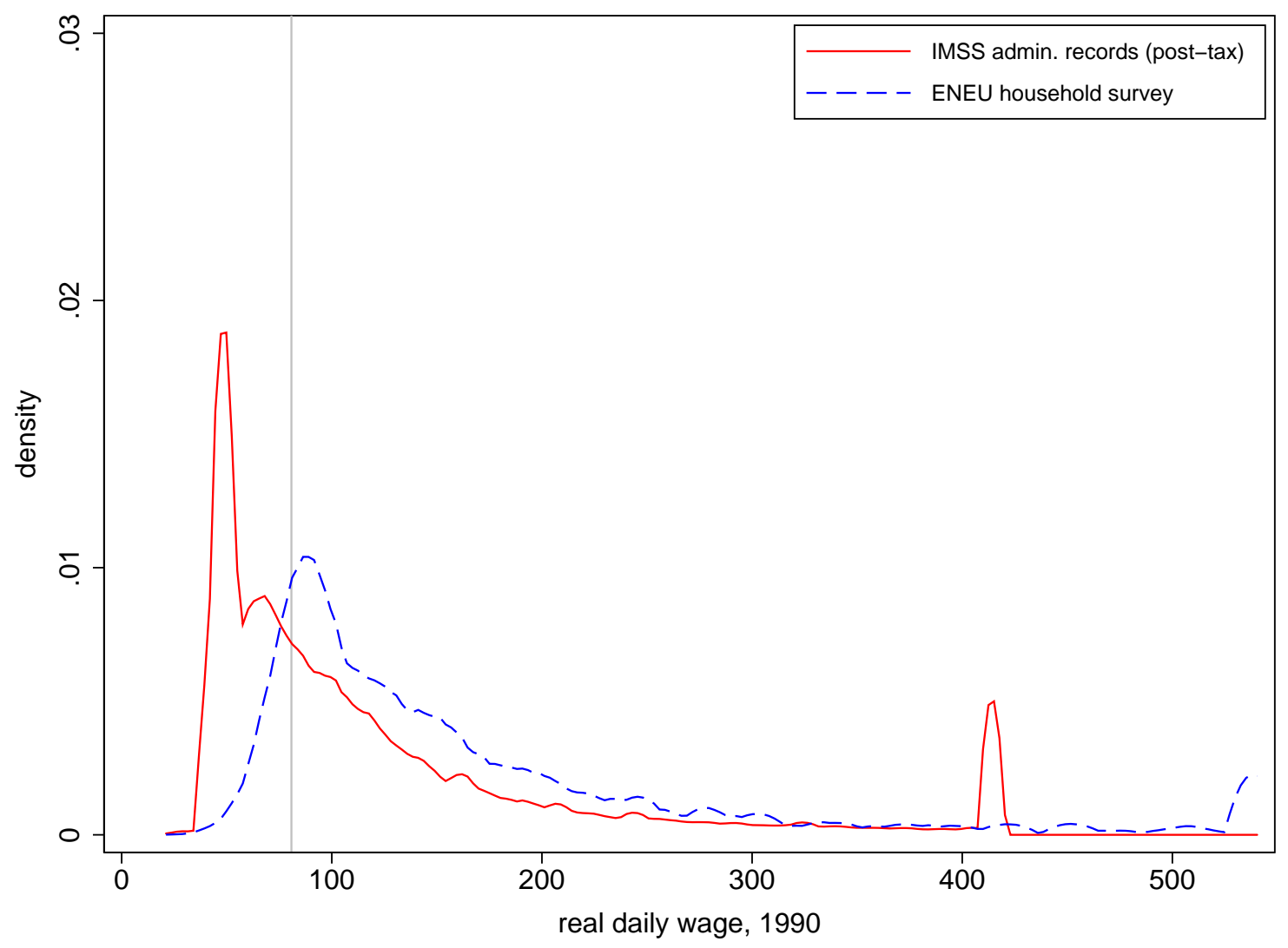

Notes: The wage variables are the real daily take-home wage from ENEU and real daily post-tax reported wage from IMSS. Densities are estimated using 1990 data and an Epanechnikov kernel with bandwidth 3 pesos for IMSS data and 6 pesos for ENEU data (using Stata kdensity command). Wages are in 2002 pesos. Average 2002 exchange rate: 9.66 pesos/dollar. (Densities are smoothed versions of histograms in Figure 6.) Vertical line is at 25th percentile of the ENEU wage distribution. Data are from second quarter of 1990. Excess mass for 25th percentile defined as (area under red, left of vertical line) - (area under blue, left of vertical line). Excess mass defined analogously for other percentiles. See Section 4 and Appendix C (online) for further details of data processing. 
Figure 10. Wage histograms, men, 1993, IMSS data, establishments linked to EIA

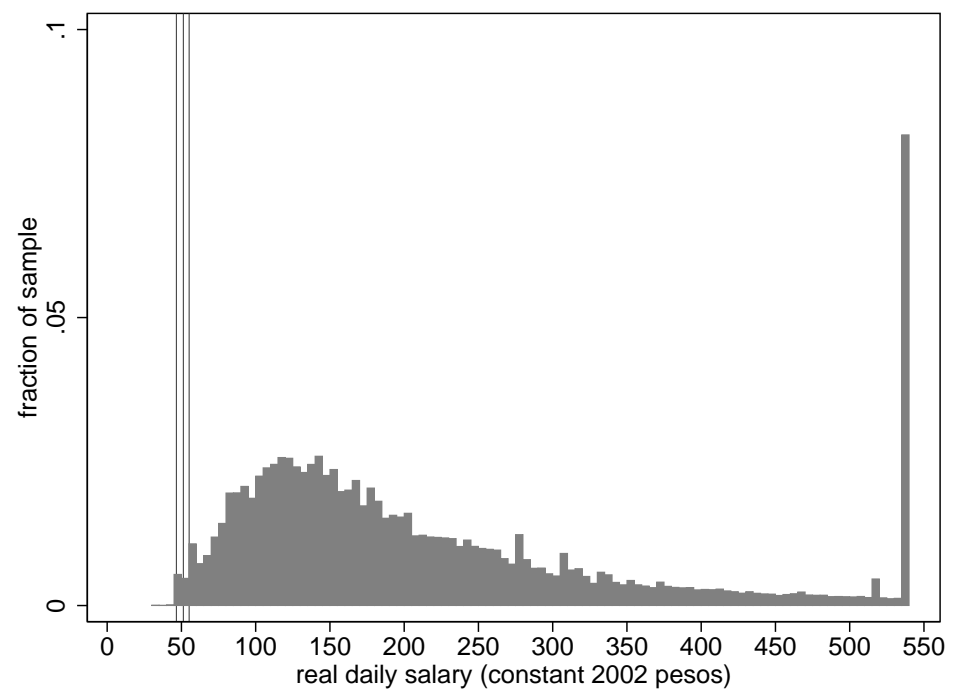

Notes: Sample is permanent male workers ages 16-65 in IMSS data in 2389 establishments that can be linked to a balanced 1993-2003 panel from the Encuesta Industrial Anual (EIA) [Annual Industrial Survey], which excludes assembly-for-export maquiladora plants. Data are from second quarter. Vertical lines indicate minimum wages in the three minimum-wage zones in Mexico (A, B, C). Bins are 5 pesos wide. See Section 4 and Appendix C (online) for further details of data processing.

Figure 11. Wage histograms, men, 1993, IMSS data, establishments linked to EMIME

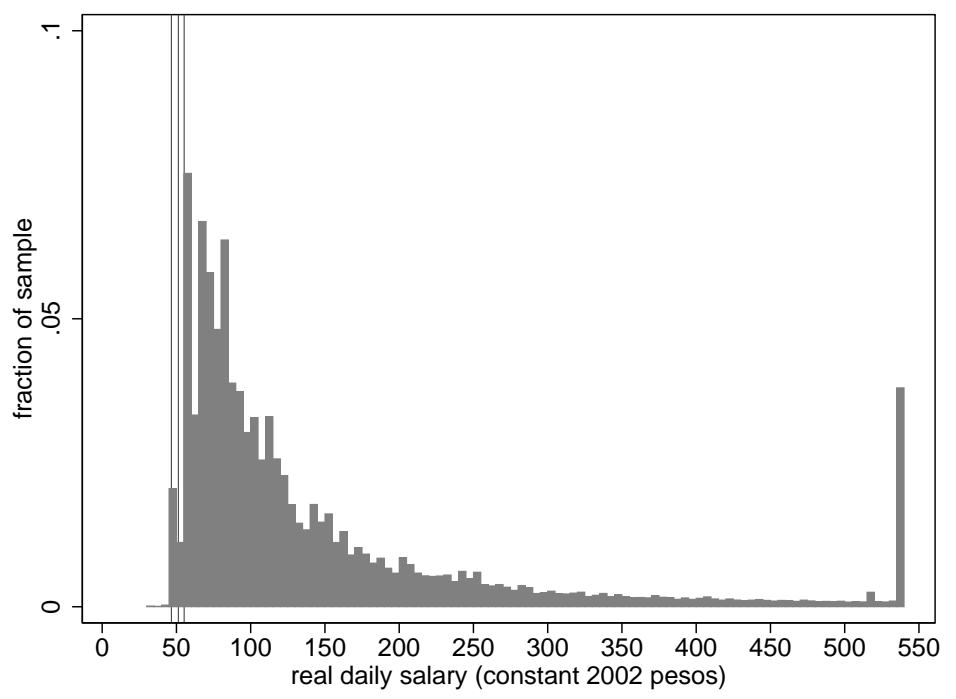

Notes: Sample is permanent male workers ages 16-65 in IMSS data in 520 establishments that can be linked to a balanced 1993-2003 panel from the Estadísticas Mensuales de la Industria Maquiladora de Exportación (EMIME) [Monthly Statistics on Maquiladora Export Industry], a dataset made up exclusively of assembly-forexport maquiladora plants. Data are from second quarter. Vertical lines indicate minimum wages in the three minimum-wage zones in Mexico (A, B, C). Bins are 5 pesos wide. See Section 4 and Appendix C (online) for further details of data processing. 
Figure 12. Wage densities by age group, 1990, 1997, 2003, men
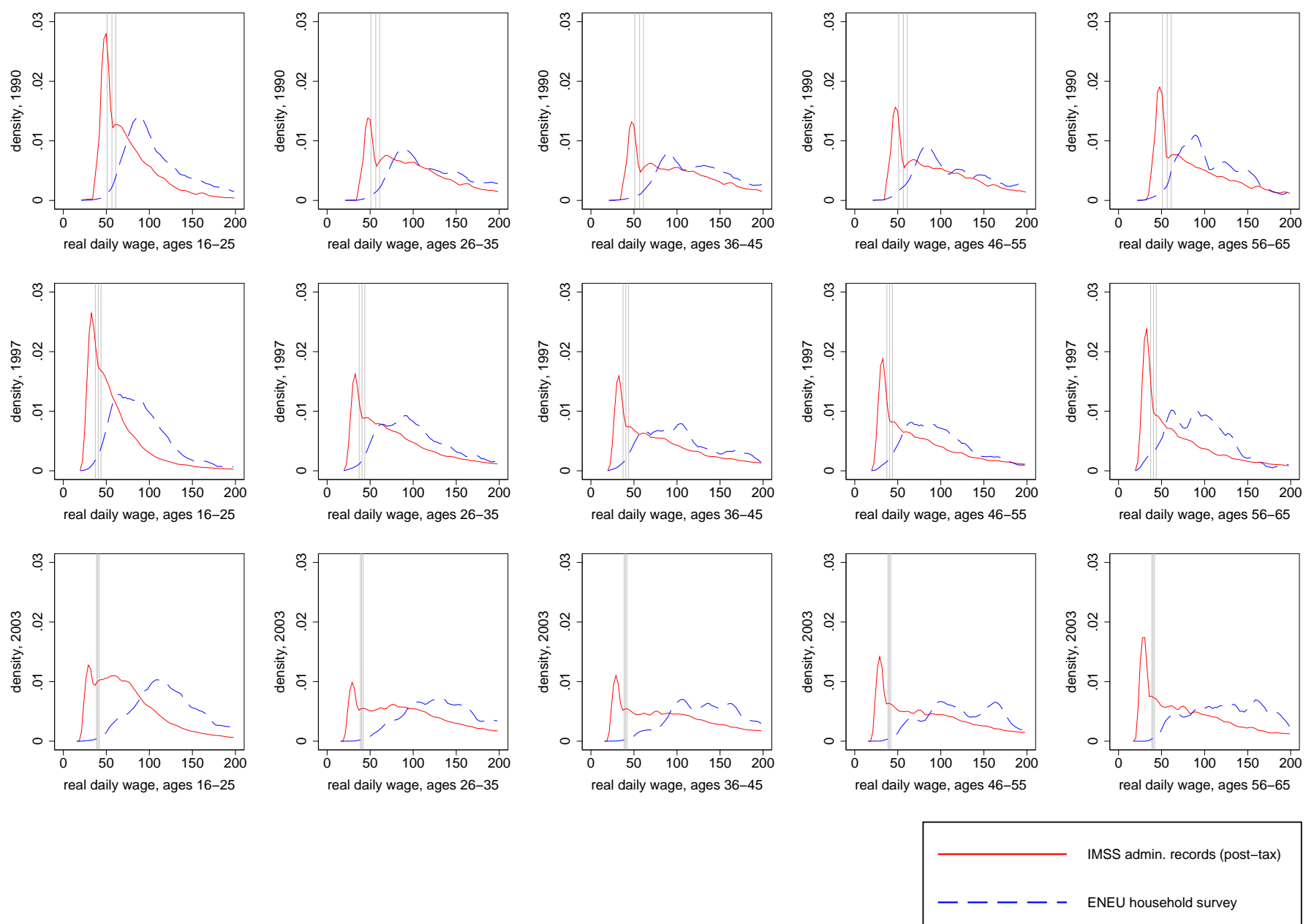

Notes: The wage variables are the real daily take-home wage from ENEU and real daily post-tax reported wage from IMSS. Densities are estimated and an Epanechnikov kernel with bandwidth 3 pesos for IMSS data and 6 pesos for ENEU data (using Stata kdensity command). Wages are in 2002 pesos. Average 2002 exchange rate: 9.66 pesos/dollar. Rows correspond to years 1990, 1997, 2003; columns to age groups 16-25, 26-35, 36-45, 46-55, 56-65. Samples are baseline samples of men, only including workers with wages less than 200 pesos/day. Data in both samples are from second quarter. See Section 4 and Appendix C (online) for further details. 
Figure 13. Wage gaps (medians) by age group, men, deviated from metro-year means

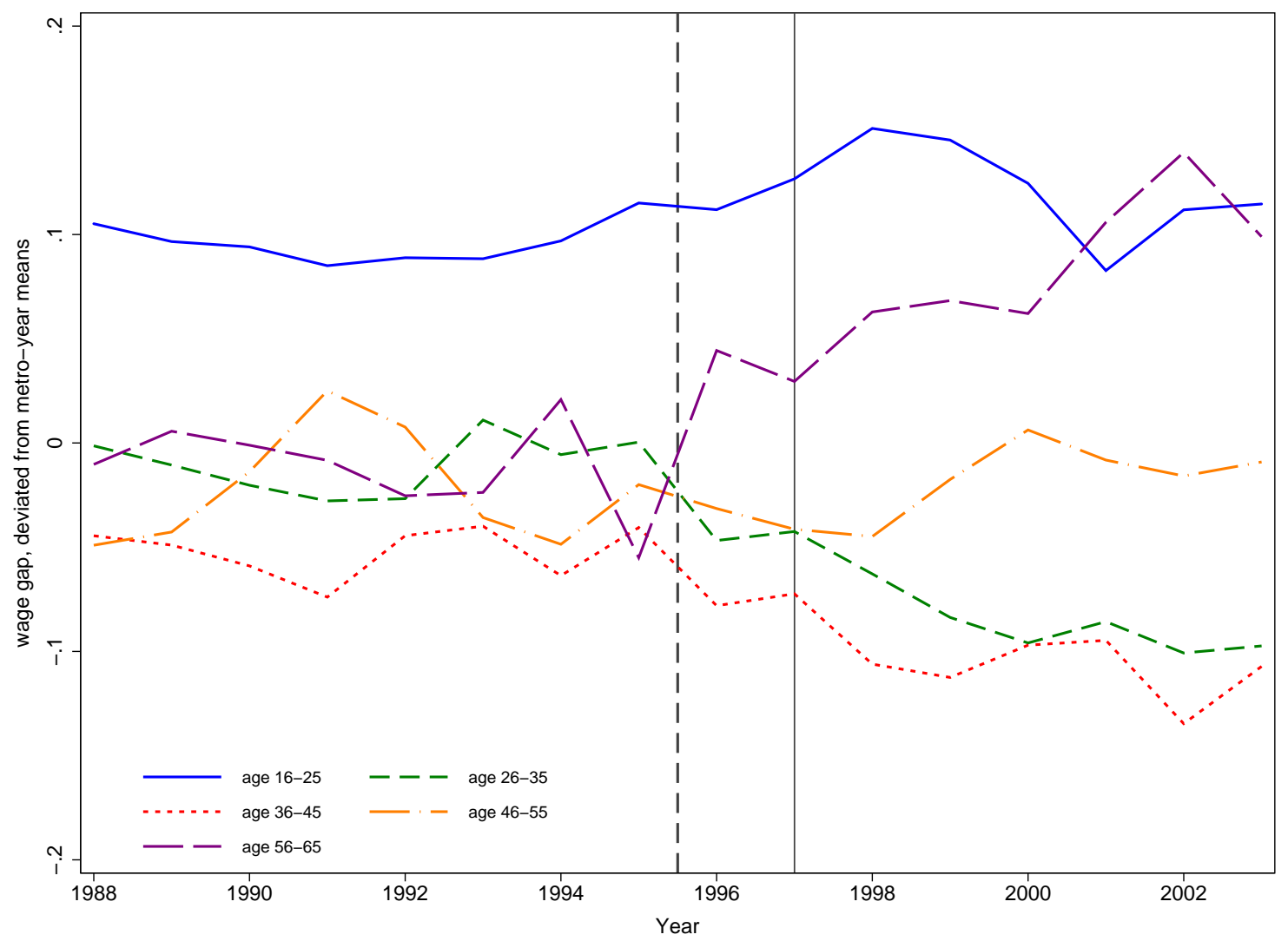

Notes: Each wage gap is the difference between the log median net wage from the ENEU survey and the log median post-tax reported wage from the IMSS administrative records, using the ENEU and IMSS baseline samples (pooling ENEU data across quarters within year). To calculate deviated wage gaps, we calculate wage gaps separately by age group-year-metro area, regress them on a full set of metro area-year dummies, and average the residuals at the age-group level. The dashed vertical line indicates the date the pension reform was passed by Congress (Dec. 21, 1995); the solid vertical line indicates the date the reform took effect (July 1, 1997). Observations correspond to the second quarter of each year. See Section 4 and Appendix C (online) for details of sample selection. 
Table 1. Pension wealth simulation, by age in 1997, male worker with 35 years of expected contributions

\begin{tabular}{|c|c|c|c|c|c|c|c|c|}
\hline \multirow{2}{*}{$\begin{array}{c}\text { Age in } \\
1997\end{array}$} & \multirow{2}{*}{$\begin{array}{l}\text { Years of Expected } \\
\text { PRA Contributions }\end{array}$} & \multirow[b]{2}{*}{ Plan } & \multicolumn{6}{|c|}{ Real Daily Wage } \\
\hline & & & 43 & 100 & 200 & 300 & 500 & 1079 \\
\hline \multirow[t]{2}{*}{25} & 35 & PRA & 398.6 & 815.0 & 1626.2 & 2437.3 & 4059.7 & 8751.9 \\
\hline & & PAYGO & 398.6 & 398.6 & 603.8 & 890.2 & 1483.6 & 3200.1 \\
\hline \multirow[t]{2}{*}{30} & 30 & PRA & 398.6 & 523.4 & 1044.3 & 1565.3 & 2607.1 & 5620.5 \\
\hline & & PAYGO & 398.6 & 398.6 & 603.8 & 890.2 & 1483.6 & 3200.1 \\
\hline \multirow[t]{2}{*}{35} & 25 & PRA & 398.6 & 398.6 & 659.1 & 987.8 & 1645.3 & 3546.9 \\
\hline & & PAYGO & 398.6 & 398.6 & 603.8 & 890.2 & 1483.6 & 3200.1 \\
\hline \multirow[t]{2}{*}{40} & 20 & PRA & 398.6 & 398.6 & 403.9 & 605.4 & 1008.4 & 2173.9 \\
\hline & & PAYGO & 398.6 & 398.6 & 603.8 & 890.2 & 1483.6 & 3200.1 \\
\hline \multirow[t]{2}{*}{45} & 15 & PRA & 398.6 & 398.6 & 398.6 & 398.6 & 586.6 & 1264.7 \\
\hline & & PAYGO & 398.6 & 398.6 & 603.8 & 890.2 & 1483.6 & 3200.1 \\
\hline \multirow[t]{2}{*}{50} & 10 & PRA & 398.6 & 398.6 & 398.6 & 398.6 & 398.6 & 662.6 \\
\hline & & PAYGO & 398.6 & 398.6 & 603.8 & 890.2 & 1483.6 & 3200.1 \\
\hline \multirow[t]{2}{*}{55} & 5 & PRA & 398.6 & 398.6 & 398.6 & 398.6 & 398.6 & 398.6 \\
\hline & & PAYGO & 398.6 & 398.6 & 603.8 & 890.2 & 1483.6 & 3200.1 \\
\hline
\end{tabular}

Notes: Values are real present discounted value of the future stream of pension benefits in thousands of 2002 pesos, for a male worker who began contributing at age 25 and expects to continue until age 60. Numbers in italics (and blue where color is available) indicate that personal retirement account (PRA) has a higher expected payoff than the pre-reform pension (PAYGO). Average 2002 exchange rate: 9.66 pesos/dollar. 43 pesos is real daily minimum wage (in Mexico City) in 1997, 1079 pesos is the topcode we impose (corresponding to the lowest real value of IMSS topcode over study period.) See Section 2.3 and Appendix A.3 (online) for further details. 
Table 2. Comparison of IMSS baseline sample and various ENEU samples, men

\begin{tabular}{|c|c|c|c|c|c|c|}
\hline & $\begin{array}{c}\text { IMSS } \\
\text { baseline } \\
\text { sample } \\
(1)\end{array}$ & $\begin{array}{c}\text { full } \\
\text { ENEU } \\
\text { sample } \\
(2)\end{array}$ & $\begin{array}{c}\text { ENEU } \\
\text { w/ IMSS } \\
(3)\end{array}$ & $\begin{array}{c}\text { ENEU } \\
\text { w/o IMSS } \\
(4)\end{array}$ & $\begin{array}{l}\text { ENEU } \\
\text { permanent } \\
\text { w/ IMSS } \\
(5)\end{array}$ & $\begin{array}{l}\text { ENEU } \\
\text { full-time } \\
\text { w/ IMSS } \\
(6)\end{array}$ \\
\hline \multicolumn{7}{|l|}{ A. 1990} \\
\hline real avg. daily post-tax wage & $\begin{array}{c}121.02 \\
(0.07)\end{array}$ & $\begin{array}{c}163.88 \\
(1.58)\end{array}$ & $\begin{array}{c}172.98 \\
(1.94)\end{array}$ & $\begin{array}{c}143.88 \\
(2.62)\end{array}$ & & $\begin{array}{c}166.73 \\
(1.85)\end{array}$ \\
\hline age & $\begin{array}{l}31.75 \\
(0.01)\end{array}$ & $\begin{array}{l}31.46 \\
(0.15)\end{array}$ & $\begin{array}{l}32.13 \\
(0.17)\end{array}$ & $\begin{array}{l}29.98 \\
(0.29)\end{array}$ & & $\begin{array}{l}32.22 \\
(0.17)\end{array}$ \\
\hline fraction employed in ests $>100$ employees & $\begin{array}{c}0.52 \\
(0.00)\end{array}$ & $\begin{array}{c}0.43 \\
(0.01)\end{array}$ & $\begin{array}{c}0.55 \\
(0.01)\end{array}$ & $\begin{array}{c}0.18 \\
(0.01)\end{array}$ & & $\begin{array}{c}0.55 \\
(0.01)\end{array}$ \\
\hline N (raw observations) & 1691417 & 16169 & 11592 & 4577 & & 10978 \\
\hline $\mathrm{N}$ (population, using weights) & 1691417 & 2578847 & 1772523 & 806324 & & 1645229 \\
\hline \multicolumn{7}{|l|}{ B. 2000} \\
\hline real avg. daily post-tax wage & $\begin{array}{c}123.60 \\
(0.07)\end{array}$ & $\begin{array}{c}148.20 \\
(1.31)\end{array}$ & $\begin{array}{c}161.15 \\
(1.60)\end{array}$ & $\begin{array}{c}120.78 \\
(2.16)\end{array}$ & $\begin{array}{c}166.42 \\
(1.80)\end{array}$ & $\begin{array}{c}155.80 \\
(1.59)\end{array}$ \\
\hline age & $\begin{array}{l}32.70 \\
(0.01)\end{array}$ & $\begin{array}{l}32.22 \\
(0.14)\end{array}$ & $\begin{array}{l}32.82 \\
(0.16)\end{array}$ & $\begin{array}{l}30.94 \\
(0.28)\end{array}$ & $\begin{array}{l}33.22 \\
(0.17)\end{array}$ & $\begin{array}{c}32.88 \\
(0.16)\end{array}$ \\
\hline fraction employed in ests $>100$ employees & $\begin{array}{c}0.58 \\
(0.00)\end{array}$ & $\begin{array}{c}0.44 \\
(0.01)\end{array}$ & $\begin{array}{c}0.59 \\
(0.01)\end{array}$ & $\begin{array}{c}0.10 \\
(0.01)\end{array}$ & $\begin{array}{c}0.63 \\
(0.01)\end{array}$ & $\begin{array}{c}0.59 \\
(0.01)\end{array}$ \\
\hline N (raw observations) & 2420307 & 19171 & 14063 & 5108 & 11918 & 13246 \\
\hline N (population, using weights) & 2420307 & 3509828 & 2384267 & 1125561 & 2042988 & 2225318 \\
\hline
\end{tabular}

Notes: All columns focus on wage-earning male workers ages 16-65 in manufacturing, construction, and retail/hotel/restaurant sectors in 16 metropolitan areas from the original ENEU sample. Column 1 reports statistics for IMSS baseline sample; Column 2 for full ENEU (household survey) sample (satisfying aforementioned criteria); Column 3 for employees in ENEU who report receiving IMSS benefit in current employment; Column 4 for employees in ENEU who report not receiving IMSS benefit; Column 5 for employees in ENEU who report receiving IMSS benefit and having a written contract of indefinite duration; and Column 6 for employees in ENEU who report receiving IMSS benefit and working at least 35 hours in previous week (the ENEU baseline sample). Standard errors of means in parentheses. In IMSS data, the fraction in establishments with $>100$ employees variable refers to permanent employees. In the ENEU survey, the establishment-size question asks the total number of employees (without specifying permanent vs. temporary.) For further details, see Section 4 and Appendix C (online). 
Table 3. Age composition by firm size category, 1990, men

\begin{tabular}{|c|c|c|c|c|c|c|}
\hline & \multicolumn{5}{|c|}{ Age category (employment as \% of row total) } & \multirow{2}{*}{$\begin{array}{c}\text { employment as } \% \\
\text { of column total }\end{array}$} \\
\hline & $16-25$ & $26-35$ & $36-45$ & $46-55$ & $56-65$ & \\
\hline \multicolumn{7}{|l|}{ A. IMSS } \\
\hline 1-10 employees & 29.9 & 32.6 & 19.8 & 11.9 & 5.8 & 14.5 \\
\hline 11-50 employees & 33.6 & 32.2 & 18.7 & 10.6 & 4.9 & 22.6 \\
\hline 51-100 employees & 35.0 & 32.5 & 18.5 & 9.8 & 4.2 & 10.8 \\
\hline 101-250 employees & 36.3 & 33.3 & 17.8 & 9.0 & 3.5 & 14.7 \\
\hline$>250$ employees & 37.7 & 34.8 & 17.5 & 7.6 & 2.5 & 37.5 \\
\hline all firm sizes & 35.1 & 33.4 & 18.3 & 9.3 & 3.8 & \\
\hline \multicolumn{7}{|l|}{ B. ENEU } \\
\hline 1-10 employees & 35.9 & 28.3 & 18.0 & 12.5 & 5.3 & 12.4 \\
\hline 11-50 employees & 33.5 & 33.3 & 18.4 & 10.3 & 4.5 & 21.0 \\
\hline 51-100 employees & 35.6 & 33.4 & 15.2 & 10.7 & 5.1 & 11.6 \\
\hline 101-250 employees & 30.2 & 31.2 & 21.5 & 12.4 & 4.7 & 10.5 \\
\hline$>250$ employees & 34.0 & 33.4 & 21.5 & 8.5 & 2.7 & 44.5 \\
\hline all firm sizes & 33.9 & 32.5 & 19.7 & 10.1 & 3.9 & \\
\hline
\end{tabular}

Notes: Data are from IMSS and ENEU baseline samples. Percentages are calculated based on employment (using sampling weights, in the case of the ENEU) in each cell. Panel B drops observations in ENEU baseline sample that are missing the firm-size variable (which make up less than $1 \%$ of sample). For further details, see Section 4 and Appendix C (online). 
Table 4. Cross-sectional patterns of evasion, 1990, men

\begin{tabular}{|c|c|c|c|c|c|c|c|c|c|}
\hline & \multicolumn{3}{|c|}{ wage gap (medians) } & \multicolumn{3}{|c|}{ wage gap (means) } & \multicolumn{3}{|c|}{ exc. mass (15th percentile) } \\
\hline & (1) & $(2)$ & $(3)$ & $(4)$ & $(5)$ & $(6)$ & $(7)$ & $(8)$ & $(9)$ \\
\hline age $26-35$ & $\begin{array}{c}-0.054^{*} \\
(0.029)\end{array}$ & & $\begin{array}{c}-0.053^{* *} \\
(0.021)\end{array}$ & $\begin{array}{c}-0.081^{* * *} \\
(0.024)\end{array}$ & & $\begin{array}{c}-0.081^{* * *} \\
(0.019)\end{array}$ & $\begin{array}{c}-0.154^{* * *} \\
(0.017)\end{array}$ & & $\begin{array}{c}-0.154^{* * *} \\
(0.013)\end{array}$ \\
\hline age $36-45$ & $\begin{array}{c}-0.072^{* *} \\
(0.034)\end{array}$ & & $\begin{array}{c}-0.072^{* * *} \\
(0.027)\end{array}$ & $\begin{array}{c}-0.150 * * * \\
(0.028)\end{array}$ & & $\begin{array}{c}-0.150^{* * *} \\
(0.024)\end{array}$ & $\begin{array}{c}-0.170 * * * \\
(0.017)\end{array}$ & & $\begin{array}{c}-0.170 * * * \\
(0.014)\end{array}$ \\
\hline age $46-55$ & $\begin{array}{l}-0.029 \\
(0.035)\end{array}$ & & $\begin{array}{l}-0.025 \\
(0.031)\end{array}$ & $\begin{array}{c}-0.154^{* * *} \\
(0.031)\end{array}$ & & $\begin{array}{c}-0.151^{* * *} \\
(0.027)\end{array}$ & $\begin{array}{c}-0.154^{* * *} \\
(0.018)\end{array}$ & & $\begin{array}{c}-0.152^{* * *} \\
(0.015)\end{array}$ \\
\hline age $56-65$ & $\begin{array}{l}-0.020 \\
(0.044)\end{array}$ & & $\begin{array}{l}-0.026 \\
(0.040)\end{array}$ & $\begin{array}{c}-0.167^{* * *} \\
(0.038)\end{array}$ & & $\begin{array}{c}-0.174^{* * *} \\
(0.035)\end{array}$ & $\begin{array}{c}-0.117^{* * *} \\
(0.020)\end{array}$ & & $\begin{array}{c}-0.119 * * * \\
(0.017)\end{array}$ \\
\hline 11-50 employees & & $\begin{array}{c}-0.333^{* * *} \\
(0.026)\end{array}$ & $\begin{array}{c}-0.333^{* * *} \\
(0.024)\end{array}$ & & $\begin{array}{c}-0.177^{* * *} \\
(0.025)\end{array}$ & $\begin{array}{c}-0.176^{* * *} \\
(0.023)\end{array}$ & & $\begin{array}{c}-0.155^{* * *} \\
(0.011)\end{array}$ & $\begin{array}{c}-0.154^{* * *} \\
(0.010)\end{array}$ \\
\hline 51-100 employees & & $\begin{array}{c}-0.475^{* * *} \\
(0.033)\end{array}$ & $\begin{array}{c}-0.469^{* * *} \\
(0.031)\end{array}$ & & $\begin{array}{c}-0.283^{* * *} \\
(0.030)\end{array}$ & $\begin{array}{c}-0.280^{* * *} \\
(0.028)\end{array}$ & & $\begin{array}{c}-0.247^{* * *} \\
(0.015)\end{array}$ & $\begin{array}{c}-0.242^{* * *} \\
(0.014)\end{array}$ \\
\hline 101-250 employees & & $\begin{array}{c}-0.395^{* * *} \\
(0.039)\end{array}$ & $\begin{array}{c}-0.374^{* * *} \\
(0.037)\end{array}$ & & $\begin{array}{c}-0.245^{* * *} \\
(0.035)\end{array}$ & $\begin{array}{c}-0.233^{* * *} \\
(0.032)\end{array}$ & & $\begin{array}{c}-0.235^{* * *} \\
(0.018)\end{array}$ & $\begin{array}{c}-0.224^{* * *} \\
(0.016)\end{array}$ \\
\hline$>250$ employees & & $\begin{array}{c}-0.500^{* * *} \\
(0.035)\end{array}$ & $\begin{array}{c}-0.464^{* * *} \\
(0.034)\end{array}$ & & $\begin{array}{c}-0.233^{* * *} \\
(0.030)\end{array}$ & $\begin{array}{c}-0.200^{* * *} \\
(0.030)\end{array}$ & & $\begin{array}{c}-0.288^{* * *} \\
(0.018)\end{array}$ & $\begin{array}{c}-0.268^{* * *} \\
(0.017)\end{array}$ \\
\hline construction & & & $\begin{array}{c}0.134^{* * *} \\
(0.029)\end{array}$ & & & $\begin{array}{c}0.122^{* * *} \\
(0.025)\end{array}$ & & & $\begin{array}{c}0.064^{* * *} \\
(0.014)\end{array}$ \\
\hline retail/services & & & $\begin{array}{c}-0.074^{* * *} \\
(0.024)\end{array}$ & & & $\begin{array}{c}-0.110^{* * *} \\
(0.021)\end{array}$ & & & $\begin{array}{c}-0.043^{* * *} \\
(0.011)\end{array}$ \\
\hline constant & $\begin{array}{c}0.559^{* * *} \\
(0.017) \\
\end{array}$ & $\begin{array}{c}0.855^{* * *} \\
(0.018)\end{array}$ & $\begin{array}{c}0.633^{* * *} \\
(0.047)\end{array}$ & $\begin{array}{c}0.501^{* * *} \\
(0.016)\end{array}$ & $\begin{array}{c}0.577^{* * *} \\
(0.018) \\
\end{array}$ & $\begin{array}{c}0.506^{* * *} \\
(0.039)\end{array}$ & $\begin{array}{c}0.519^{* * *} \\
(0.010)\end{array}$ & $\begin{array}{c}0.578^{* * *} \\
(0.007)\end{array}$ & $\begin{array}{c}0.566^{* * *} \\
(0.019) \\
\end{array}$ \\
\hline metro area effects & $\mathrm{N}$ & $\mathrm{N}$ & $\mathrm{Y}$ & $\mathrm{N}$ & $\mathrm{N}$ & $\mathrm{Y}$ & $\mathrm{N}$ & $\mathrm{N}$ & Y \\
\hline R-squared & 0.00 & 0.20 & 0.31 & 0.03 & 0.09 & 0.27 & 0.09 & 0.24 & 0.44 \\
\hline $\mathrm{N}$ & 1062 & 1062 & 1062 & 1062 & 1062 & 1062 & 1062 & 1062 & 1062 \\
\hline
\end{tabular}

Notes: Data are from IMSS and ENEU baseline samples, collapsed to metro area/age group/firm-size category/sector level for 1990. The omitted category for age is 16-25, for firm size is 1-10 employees, and for sector is manufacturing. The wage gap (medians) is log median real daily take-home wage from the ENEU minus log median real daily post-tax reported wage from IMSS, calculated. Wage gap (means) is analogous, using mean in place of median. Excess mass is calculated as described in Section 5 and Figure 9. In calculating evasion measures, we pool ENEU data across quarters within year. *** $1 \%$, ** $5 \%, * 10 \%$ level. See Section 4 and Appendix $\mathrm{C}$ (online) for further details of data processing. 
Table 5. Differential effects of pension reform on evasion, men

\begin{tabular}{|c|c|c|c|}
\hline & $\begin{array}{c}\text { wage gap } \\
\text { (medians) } \\
(1)\end{array}$ & $\begin{array}{c}\text { wage gap } \\
\text { (means) } \\
(2)\end{array}$ & $\begin{array}{c}\text { excess mass } \\
\left(15^{t h} \text { perc. }\right) \\
(3)\end{array}$ \\
\hline $1($ age $<=55) * 1988$ & $\begin{array}{c}0.050 \\
(0.037)\end{array}$ & $\begin{array}{c}-0.069^{* *} \\
(0.031)\end{array}$ & $\begin{array}{c}0.019 \\
(0.020)\end{array}$ \\
\hline $1($ age $<=55) * 1989$ & $\begin{array}{c}0.030 \\
(0.042)\end{array}$ & $\begin{array}{c}-0.077^{* *} \\
(0.036)\end{array}$ & $\begin{array}{c}0.004 \\
(0.016)\end{array}$ \\
\hline $1($ age $<=55) * 1990$ & $\begin{array}{c}0.038 \\
(0.040)\end{array}$ & $\begin{array}{c}-0.089 * * \\
(0.038)\end{array}$ & $\begin{array}{l}-0.002 \\
(0.015)\end{array}$ \\
\hline $1($ age $<=55) * 1991$ & $\begin{array}{c}0.047 \\
(0.039)\end{array}$ & $\begin{array}{l}-0.069^{*} \\
(0.040)\end{array}$ & $\begin{array}{l}-0.020 \\
(0.014)\end{array}$ \\
\hline $1($ age $<=55) * 1992$ & $\begin{array}{c}0.069 \\
(0.043)\end{array}$ & $\begin{array}{l}-0.016 \\
(0.042)\end{array}$ & $\begin{array}{c}0.007 \\
(0.016)\end{array}$ \\
\hline $1($ age $<=55) * 1993$ & $\begin{array}{l}0.067^{*} \\
(0.040)\end{array}$ & $\begin{array}{l}-0.032 \\
(0.038)\end{array}$ & $\begin{array}{c}0.014 \\
(0.017)\end{array}$ \\
\hline $1($ age $<=55) * 1994$ & $\begin{array}{c}0.011 \\
(0.045)\end{array}$ & $\begin{array}{l}-0.062^{*} \\
(0.035)\end{array}$ & $\begin{array}{c}0.019 \\
(0.016)\end{array}$ \\
\hline $1($ age $<=55) * 1995$ & $\begin{array}{c}0.106^{* *} \\
(0.045)\end{array}$ & $\begin{array}{l}-0.029 \\
(0.031)\end{array}$ & $\begin{array}{c}0.017 \\
(0.017)\end{array}$ \\
\hline $1($ age $<=55) * 1996$ & $\begin{array}{l}-0.019 \\
(0.040)\end{array}$ & $\begin{array}{c}-0.087^{*} \\
(0.046)\end{array}$ & $\begin{array}{l}-0.023 \\
(0.017)\end{array}$ \\
\hline $1($ age $<=55) * 1998$ & $\begin{array}{l}-0.042 \\
(0.037)\end{array}$ & $\begin{array}{c}-0.093^{* * *} \\
(0.035)\end{array}$ & $\begin{array}{c}-0.023^{*} \\
(0.014)\end{array}$ \\
\hline $1($ age $<=55) * 1999$ & $\begin{array}{l}-0.048 \\
(0.041)\end{array}$ & $\begin{array}{c}-0.129 \text { *** } \\
(0.036)\end{array}$ & $\begin{array}{c}-0.035^{* *} \\
(0.015)\end{array}$ \\
\hline $1(\text { age }<=55)^{*} 2000$ & $\begin{array}{l}-0.041 \\
(0.039)\end{array}$ & $\begin{array}{c}-0.133^{* * *} \\
(0.029)\end{array}$ & $\begin{array}{c}-0.034^{* *} \\
(0.013)\end{array}$ \\
\hline $1($ age $<=55) * 2001$ & $\begin{array}{c}-0.095^{* *} \\
(0.047)\end{array}$ & $\begin{array}{c}-0.181^{* * *} \\
(0.039)\end{array}$ & $\begin{array}{c}-0.045^{* * *} \\
(0.015)\end{array}$ \\
\hline $1($ age $<=55) * 2002$ & $\begin{array}{c}-0.137^{* * *} \\
(0.039)\end{array}$ & $\begin{array}{c}-0.218^{* * *} \\
(0.034)\end{array}$ & $\begin{array}{c}-0.032^{* *} \\
(0.015)\end{array}$ \\
\hline $1($ age $<=55) * 2003$ & $\begin{array}{c}-0.087^{* *} \\
(0.040) \\
\end{array}$ & $\begin{array}{c}-0.204^{* * *} \\
(0.035) \\
\end{array}$ & $\begin{array}{c}-0.029 * \\
(0.015) \\
\end{array}$ \\
\hline age group-metro area effects & Y & Y & Y \\
\hline metro-year effects & $\mathrm{Y}$ & $\mathrm{Y}$ & $\mathrm{Y}$ \\
\hline R-squared & 0.92 & 0.89 & 0.96 \\
\hline $\mathrm{N}$ & 1280 & 1280 & 1280 \\
\hline
\end{tabular}

Notes: Data are from IMSS and ENEU baseline samples, collapsed to metro area/age group/year level. Wage gap (medians) is log median real daily net wage from ENEU minus log median post-tax daily wage from IMSS. Wage gap (means) is defined analogously, using means in place of medians. Excess mass is calculated as described in Section 5 and Figure 9. In calculating evasion measures, we pool ENEU data across quarters within year. *** $1 \%$, ** 5\%, * $10 \%$ level. See Section 4 and Appendix C (online) for further details of data processing. 
Table 6. Differential effects of pension reform on employment gap, men

\begin{tabular}{|c|c|c|}
\hline & \multicolumn{2}{|c|}{ dep. var.: $\log ($ empl., ENEU $)-\log ($ empl., IMSS $)$} \\
\hline $1(\text { age }<=55)^{*} 1988$ & $\begin{array}{c}0.035 \\
(0.100)\end{array}$ & $\begin{array}{c}0.035 \\
(0.090)\end{array}$ \\
\hline $1($ age $<=55) * 1989$ & $\begin{array}{l}-0.040 \\
(0.104)\end{array}$ & $\begin{array}{l}-0.040 \\
(0.087)\end{array}$ \\
\hline $1(\operatorname{age}<=55) * 1990$ & $\begin{array}{l}-0.065 \\
(0.097)\end{array}$ & $\begin{array}{l}-0.065 \\
(0.091)\end{array}$ \\
\hline $1(\operatorname{age}<=55)^{*} 1991$ & $\begin{array}{l}-0.100 \\
(0.109)\end{array}$ & $\begin{array}{l}-0.100 \\
(0.098)\end{array}$ \\
\hline $1(\operatorname{age}<=55)^{*} 1992$ & $\begin{array}{l}-0.044 \\
(0.100)\end{array}$ & $\begin{array}{l}-0.044 \\
(0.083)\end{array}$ \\
\hline $1(\operatorname{age}<=55) * 1993$ & $\begin{array}{l}-0.090 \\
(0.092)\end{array}$ & $\begin{array}{l}-0.090 \\
(0.076)\end{array}$ \\
\hline $1(\text { age }<=55)^{*} 1994$ & $\begin{array}{c}0.231^{* *} \\
(0.101)\end{array}$ & $\begin{array}{c}0.231^{* * *} \\
(0.082)\end{array}$ \\
\hline $1(\operatorname{age}<=55) * 1995$ & $\begin{array}{l}-0.017 \\
(0.108)\end{array}$ & $\begin{array}{l}-0.017 \\
(0.093)\end{array}$ \\
\hline $1($ age $<=55) * 1996$ & $\begin{array}{l}-0.003 \\
(0.102)\end{array}$ & $\begin{array}{l}-0.003 \\
(0.092)\end{array}$ \\
\hline $1($ age $<=55) * 1998$ & $\begin{array}{l}-0.042 \\
(0.104)\end{array}$ & $\begin{array}{l}-0.042 \\
(0.092)\end{array}$ \\
\hline $1($ age $<=55) * 1999$ & $\begin{array}{l}-0.027 \\
(0.106)\end{array}$ & $\begin{array}{l}-0.027 \\
(0.096)\end{array}$ \\
\hline $1(\text { age }<=55)^{*} 2000$ & $\begin{array}{c}0.011 \\
(0.094)\end{array}$ & $\begin{array}{c}0.011 \\
(0.084)\end{array}$ \\
\hline $1(\text { age }<=55)^{*} 2001$ & $\begin{array}{l}-0.009 \\
(0.105)\end{array}$ & $\begin{array}{l}-0.009 \\
(0.098)\end{array}$ \\
\hline $1(\text { age }<=55)^{*} 2002$ & $\begin{array}{l}-0.087 \\
(0.103)\end{array}$ & $\begin{array}{l}-0.087 \\
(0.089)\end{array}$ \\
\hline $1($ age $<=55) * 2003$ & $\begin{array}{c}-0.033 \\
(0.091) \\
\end{array}$ & $\begin{array}{l}-0.033 \\
(0.080)\end{array}$ \\
\hline age group effects & $\mathrm{Y}$ & \\
\hline age group-metro area effects & $\mathrm{N}$ & $\mathrm{Y}$ \\
\hline metro-year effects & $\mathrm{Y}$ & $\mathrm{Y}$ \\
\hline R-squared & 0.55 & 0.68 \\
\hline $\mathrm{N}$ & 1280 & 1280 \\
\hline
\end{tabular}

Notes: Samples are IMSS and ENEU baseline samples, collapsed to metro area/age group/year level. ${ }^{* * *} 1 \%,{ }^{* *}$ $5 \%, * 10 \%$ level. See Section 4 and Appendix C (online) for further details of data processing. 
Table 7. Differential effects of pension reform on ENEU take-home wage, men

\begin{tabular}{|c|c|c|c|c|c|}
\hline \multirow{4}{*}{$1(\text { age }<=55)^{*} 1988$} & \multicolumn{5}{|c|}{ dep. var.: log daily net wage, ENEU } \\
\hline & \multirow{3}{*}{$\begin{array}{c}(1) \\
0.034 \\
(0.037)\end{array}$} & \multirow{3}{*}{$\begin{array}{c}(2) \\
0.058^{*} \\
(0.031)\end{array}$} & \multirow{3}{*}{$\begin{array}{c}(3) \\
0.055^{* *} \\
(0.027)\end{array}$} & \multirow{3}{*}{$\begin{array}{c}(4) \\
0.059 * * \\
(0.026)\end{array}$} & \multirow{3}{*}{$\begin{array}{c}(5) \\
0.060^{* *} \\
(0.026)\end{array}$} \\
\hline & & & & & \\
\hline & & & & & \\
\hline \multirow[t]{2}{*}{$1(\text { age }<=55)^{*} 1989$} & 0.010 & 0.023 & 0.041 & $0.051^{*}$ & $0.052^{*}$ \\
\hline & $(0.040)$ & $(0.034)$ & $(0.030)$ & $(0.030)$ & $(0.030)$ \\
\hline \multirow[t]{2}{*}{$1($ age $<=55) * 1990$} & 0.021 & 0.040 & $0.059 * *$ & $0.064^{* *}$ & $0.065^{* *}$ \\
\hline & $(0.040)$ & $(0.034)$ & $(0.029)$ & $(0.029)$ & $(0.029)$ \\
\hline \multirow[t]{2}{*}{$1($ age $<=55) * 1991$} & 0.041 & 0.038 & 0.040 & $0.050^{*}$ & $0.052^{*}$ \\
\hline & $(0.039)$ & $(0.033)$ & $(0.029)$ & $(0.028)$ & $(0.028)$ \\
\hline \multirow[t]{2}{*}{$1(\text { age }<=55)^{*} 1992$} & 0.040 & 0.049 & $0.054^{*}$ & $0.061^{* *}$ & $0.059^{* *}$ \\
\hline & $(0.042)$ & $(0.033)$ & $(0.030)$ & $(0.030)$ & $(0.030)$ \\
\hline \multirow[t]{2}{*}{$1(\text { age }<=55)^{*} 1993$} & 0.068 & 0.036 & $0.063^{* *}$ & $0.067^{* *}$ & $0.070^{* *}$ \\
\hline & $(0.043)$ & $(0.035)$ & $(0.032)$ & $(0.031)$ & $(0.031)$ \\
\hline \multirow[t]{2}{*}{$1(\text { age }<=55)^{*} 1994$} & -0.028 & -0.013 & -0.005 & -0.002 & -0.001 \\
\hline & $(0.043)$ & $(0.035)$ & $(0.032)$ & $(0.032)$ & $(0.032)$ \\
\hline \multirow[t]{2}{*}{$1(\text { age }<=55)^{*} 1995$} & -0.024 & -0.013 & 0.010 & 0.017 & 0.022 \\
\hline & $(0.043)$ & $(0.036)$ & $(0.032)$ & $(0.032)$ & $(0.031)$ \\
\hline \multirow[t]{2}{*}{$1(\text { age }<=55)^{*} 1996$} & -0.056 & -0.045 & -0.033 & -0.021 & -0.018 \\
\hline & $(0.043)$ & $(0.035)$ & $(0.031)$ & $(0.030)$ & $(0.030)$ \\
\hline \multirow[t]{2}{*}{$1($ age $<=55) * 1998$} & -0.037 & -0.009 & 0.009 & 0.016 & 0.019 \\
\hline & $(0.044)$ & $(0.036)$ & $(0.030)$ & $(0.030)$ & $(0.030)$ \\
\hline \multirow{2}{*}{$1(\text { age }<=55)^{*} 1999$} & -0.016 & 0.043 & $0.053^{*}$ & $0.068^{* *}$ & $0.069^{* *}$ \\
\hline & $(0.040)$ & $(0.032)$ & $(0.028)$ & $(0.028)$ & $(0.028)$ \\
\hline \multirow[t]{2}{*}{$1(\text { age }<=55)^{*} 2000$} & 0.019 & $0.077^{* *}$ & $0.065^{* *}$ & $0.072^{* *}$ & $0.072^{* *}$ \\
\hline & $(0.040)$ & $(0.034)$ & $(0.030)$ & $(0.030)$ & $(0.030)$ \\
\hline \multirow[t]{2}{*}{$1(\text { age }<=55)^{*} 2001$} & -0.018 & $0.057^{*}$ & $0.055^{*}$ & $0.061^{* *}$ & $0.062^{* *}$ \\
\hline & $(0.040)$ & $(0.032)$ & $(0.028)$ & $(0.028)$ & $(0.027)$ \\
\hline \multirow[t]{2}{*}{$1(\text { age }<=55)^{*} 2002$} & -0.062 & 0.031 & 0.022 & 0.026 & 0.028 \\
\hline & $(0.039)$ & $(0.031)$ & $(0.027)$ & $(0.027)$ & $(0.027)$ \\
\hline \multirow[t]{2}{*}{$1(\text { age }<=55)^{*} 2003$} & -0.015 & 0.038 & 0.040 & 0.049 & $0.053^{*}$ \\
\hline & $(0.044)$ & $(0.037)$ & $(0.033)$ & $(0.032)$ & $(0.032)$ \\
\hline age group effects & $\mathrm{Y}$ & $\mathrm{Y}$ & $\mathrm{Y}$ & $\mathrm{Y}$ & $\mathrm{Y}$ \\
\hline metro-year effects & $\mathrm{Y}$ & $\mathrm{Y}$ & $\mathrm{Y}$ & $\mathrm{Y}$ & $\mathrm{Y}$ \\
\hline schooling effects & $\mathrm{N}$ & $\mathrm{Y}$ & $\mathrm{Y}$ & $\mathrm{Y}$ & $\mathrm{Y}$ \\
\hline married indicator & $\mathrm{N}$ & $\mathrm{Y}$ & $\mathrm{Y}$ & $\mathrm{Y}$ & $\mathrm{Y}$ \\
\hline occupation effects & $\mathrm{N}$ & $\mathrm{N}$ & $\mathrm{Y}$ & $\mathrm{Y}$ & $\mathrm{Y}$ \\
\hline industry effects & $\mathrm{N}$ & $\mathrm{N}$ & $\mathrm{N}$ & $\mathrm{Y}$ & $\mathrm{Y}$ \\
\hline firm-size effects & $\mathrm{N}$ & $\mathrm{N}$ & $\mathrm{N}$ & $\mathrm{N}$ & $\mathrm{Y}$ \\
\hline R-squared & 0.13 & 0.40 & 0.46 & 0.47 & 0.48 \\
\hline $\mathrm{N}$ & 667566 & 667566 & 667566 & 667566 & 667566 \\
\hline
\end{tabular}

Notes: Sample is ENEU baseline sample. Take-home wage is the post-payroll-tax net wage as reported on ENEU. Estimates use population sampling weights provided in ENEU dataset. Controls include sets of 9 schooling indicators, 22 occupation indicators, and/or 50 industry indicators, in addition to the sets of five age-group and firm-size indicators, in indicated columns; details of category definitions are in Appendix C (online). *** $1 \%,{ }^{* *} 5 \%, * 10 \%$ level. 